\title{
Re-evaluation of the stratigraphically important olenellid trilobite Holmia cf. mobergi from the Cambrian Series 2, Stage 3 and its implications for the lower Cambrian stratigraphy in the Miøsa area, Norway
}

\author{
Magne Høyberget ${ }^{1}$, Jan Ove R. Ebbestad ${ }^{2} \&$ Biørn Funke ${ }^{3}$
}

\author{
${ }^{1}$ Rennesveien 14, N-4513 Mandal, Norway. \\ ${ }^{2}$ Museum of Evolution, Uppsala University, Norbyvägen 16, SE-752 36 Uppsala, Sweden. \\ ${ }^{3}$ Gjelleråsveien 10, N-1481 Hagan, Norway. \\ E-mail corresponding author (Magne Høyberget): magne.hoyberget@mandal.kommune.no
}

\begin{abstract}
The olenellid trilobite Holmia cf. mobergi, known from a single cephalon in the upper lower Cambrian strata from a river section in Flagstadelva, Hamar, has played a significant stratigraphic role in interpreting the lower Cambrian informal Series 2, Stage 3 in the Mjøsa area, Norway, since its discovery in the early 1950s. It was considered one of the oldest trilobite taxa in the lower Cambrian of Scandinavia, but the stratigraphic level and biozonation of the cephalon were problematic and a matter of discussion for decades. Moreover, organic-walled microfossil biostratigraphy questioned the supposed age of the trilobite. New specimens of this taxon collected from the type locality show that the species occurs at a different stratigraphic level than first reported, prompting a new description of the species and a re-evaluation of the taxon's biostratigraphic significance. Holmia cf. mobergi is compared with new and well-preserved topotype material of Holmia inusitata, a very rare taxon hitherto known from one single outcrop in an autochthonous setting in Norway. Holmia cf. mobergi and Holmia inusitata are here considered conspecific.
\end{abstract}

Keywords: Cambrian Series 2, biostratigraphy, Holmia, ontogeny, Mjøsa area - Norway

Received 8. November 2018 / Accepted 14. February 2019 / Published online 13. September 2019

\section{Introduction}

The well-exposed upper lower Cambrian section along the river Flagstadelva on the east side of Lake Mjøsa, Norway, has played a key role in establishing the lower Cambrian lithostratigraphy and biostratigraphy of the Mjøsa area in particular and Baltoscandia in general. The section was presented in a number of publications by Henningsmoen (1956, 1960), later described and interpreted as autochthonous by Skjeseth (1963), but more recently considered as parautochthonous or alternatively the proximal part of the Lower Allochthon (Nielsen \& Schovsbo, 2007, 2011). Simplified logs of the section have been published by Moczydłowska \& Vidal
(1986), Vidal \& Nystuen (1990) and Nielsen \& Schovsbo $(2007,2011)$.

A single cephalon of an olenellid trilobite collected at the Flagstadelva section by the Norwegian geologist Steinar Skjeseth in the early 1950s was initially referred to Holmia cf. mickwitzi (Schmidt) by Henningsmoen (1956). Based on unpublished observations by Skjeseth, he reported this specimen from the stratigraphically lowermost fossil-bearing unit in the Mjøsa area, below occurrences of the problematic fossil Discinella (= Mobergella) holsti Moberg and established a new faunal zone, 1aa. . Skjeseth $(1963$, p. 46) later concurred and termed the unit the Brennsæter Limestone. Such a low occurrence indicated a correlation with the Schmidtiellus 
mickwitzi Zone in Baltica and thus older than what had earlier been regarded as the oldest fossil-bearing Cambrian zone in the Mjøsa area (e.g., Kiær, 1917; Vogt, 1924).

Daily (1972) questioned the presence of a faunal zone below M. holsti in Flagstadelva. Based on his investigation of the section, he found that faulting had duplicated the lower part, suggesting that the zonation introduced already by Henningsmoen (1956) was problematic. Later, Martinsson (1974) referred the Flagstadelva specimen to Schmidtiellus and found it even older than S. mickwitzi in Estonia. This was based on a report of Platysolenites antiquissimus Eichwald from a basal section at the shore of Lake Mjøsa, interpreted as time-equivalent to the unit in Flagstadelva. Subsequently, the single cephalon, its presumed antiquity and biostratigraphic significance have been referred to in a number of publications (Bengtson, 1977; Føyn \& Glaessner, 1979; Bergström, 1980, 1981; Vidal, 1981a, b; Ahlberg, 1984, 1985; Bergström \& Gee, 1985; Ahlberg et al., 1986; Mens et al., 1990; Vidal \& Nystuen, 1990; Moczydłowska, 1991, 2002; Jensen, 1997; Liebermann, 1999; Moczydłowska et al., 2001; Ebbestad et al., 2003; Nielsen \& Schovsbo, 2007, 2011).
Several ardent attempts have been made to search for more fossil material from the assumed trilobite-yielding, pyrite-rich, silty limestone in the basal part of the section, regrettably without any reported results, e.g., B. Daily and G. Hamar (Daily, 1972), field notes from 1975 by Henningsmoen (stored at the Natural History Museum in Oslo, Norway), and Føyn \& Glaessner (1979, p. 41) list K. Bjørlykke, J. Bergström, P. Ahlberg, G. Bylund, J.P. Nystuen, and G. Vidal as researchers who have re-investigated the section during the 1970s.

Recent research by the present authors has revealed new and important information, which forces new attention to the stratigraphy, the lower Cambrian faunal content, and the detailed biostratigraphy and stratigraphy of the Mjøsa area. The aim of this work is to a) clarify the stratigraphic occurrence of Holmia cf. mobergi, b) revise this stratigraphically important specimen, hitherto described under open nomenclature, c) contribute to the understanding of the faunal zonation of the oldest fossil-bearing strata in the Mjøsa area, and d) constrain the timing of the sea-level transgression postdating the Hawke Bay unconformity in the parautochthonous and autochthonous settings of the Mjøsa area.

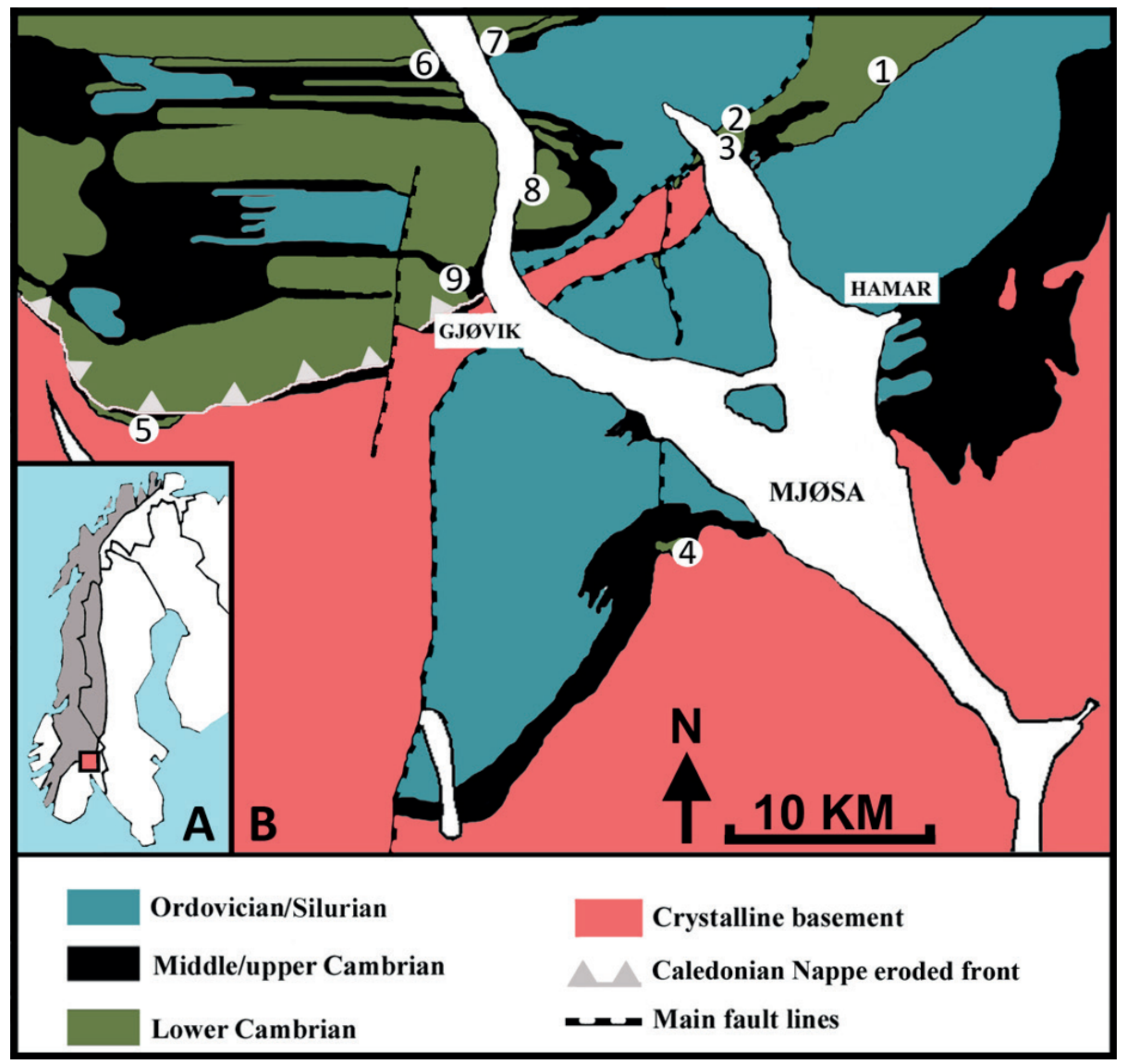

Figure 1. Simplified geological map of the Mjøsa area. (A) The Scandinavian peninsula with the Caledonides shaded and the study area marked by a red square. (B) Numbered outcrops of important lower Cambrian sections mentioned in the text. 1 - Flagstadelva, 2 - Sollerud, 3 - Langodden, all parautochthonous. 4 - Risbekken, 5 - Lauselva, both autochthonous. 6 - Redalen, 7 - Ringsaker north, 8 - Ringsaker south, 9 - Bråstadelva and Seterelva, all Lower Allochthon. 


\section{Geological setting and biostratigraphy in the Miøsa area}

The lower Cambrian strata of the Mjøsa area are present in different tectonostratigraphic settings: allochthon, parautochthon and autochthon. The Caledonian nappe front is followed along an eroded border on the west side of Lake Mjøsa and along a main fault line north-eastwards from the east side of the lake (Fig. 1). Sediments in the Lower Allochthon Osen-Røa Nappe Complex were deposited at least $140-150 \mathrm{~km}$ to the northwest of the thin autochthonous sedimentary cover, as suggested by palinspastic restoration of the décollement sheet (Nystuen, 1981). The autochthonous strata overlie the peneplained crystalline basement. In addition to the allochthonous and autochthonous deposits, slightly thrusted parautochthonous Cambrian to Silurian strata are found southeast of the main fault line on both sides of Lake Mjøsa (Nielsen \& Schovsbo, 2007, 2011). The Caledonian Lower Allochthon and parautochthonous fossiliferous strata rest unconformably on the lower Cambrian unfossiliferous (except for trace fossils) thick quartzites of the Ringsaker Member of the Vangsåsen Formation (Fig. 2). The transgressive lower Cambrian successions in the Mjøsa area were deposited during major marine-flooding events from the northwest (Skjeseth, 1963, plate 2) (present-day orientation).

Besides the use of organic-walled microfossils (OWM) as biostratigraphic markers (e.g., Moczydłowska \& Vidal, 1986, Moczydłowska, 1991, 2002), trilobites provide the best tool for the detailed Cambrian biostratigraphic framework in Scandinavia. In the Miaolingian and the Furongian, the trilobites (and agnostoids) show a considerably faster radiation than the OWMs, although less so in the lower part of Cambrian Series 2 that is hampered by rare occurrences of trilobites in the strata below the Holmia kjerulfi Zone.

Bergström (1980, 1981) introduced the Schmidtiellus mickwitzi Zone in the Mjøsa area, which was maintained by Bergström \& Gee (1985) and Ahlberg et al. (1986), based on the single occurrence of the trilobite specimen that Skjeseth had collected from the Flagstadelva section (locality 1 in Fig. 1). This specimen was compared with Holmia mobergi Bergström from the Norretorp Formation in Scania, southern Sweden, and figured and described for the first time as Holmia cf. mobergi by Ahlberg et al. (1986, pp. 47-49, fig. 6). The supposed coeval Norretorp Formation in southern Sweden corresponds to the Schmidtiellus mickwitzi Zone and is, together with the lower part of the Grammajukku Formation at Storuman in southern Swedish Lapland, the lowermost trilobite-bearing unit in Scandinavia (Moczydłowska, 2002).

A new trilobite zone was established by Ahlberg \& Bergström (1978, fig. 1) in an interval between the S. mickwitzi Zone and the $H$. kjerulfi Zone, based on three olenellid remains from an autochthonous locality at Lauselva west of Lake Mjøsa (locality 5 in Fig. 1, see detailed description in Ebbestad et al., 2003). These remains were formally described as Holmia inusitata (Ahlberg \& Bergström in Ahlberg et al., 1986) and the zone was named the Holmia inusitata Zone. Moczydłowska (1991) included the $H$. inusitata and $H$. kjerulfi zones in a new Holmia kjerulfi Assemblage Zone, not to be confused with the Holmia kjerulfi Group Zone, established by Bergström \& Ahlberg (1981) for a highly condensed sequence in the lower part of the Gislöv Formation in Scania, Sweden. The term 'Holmia Series'

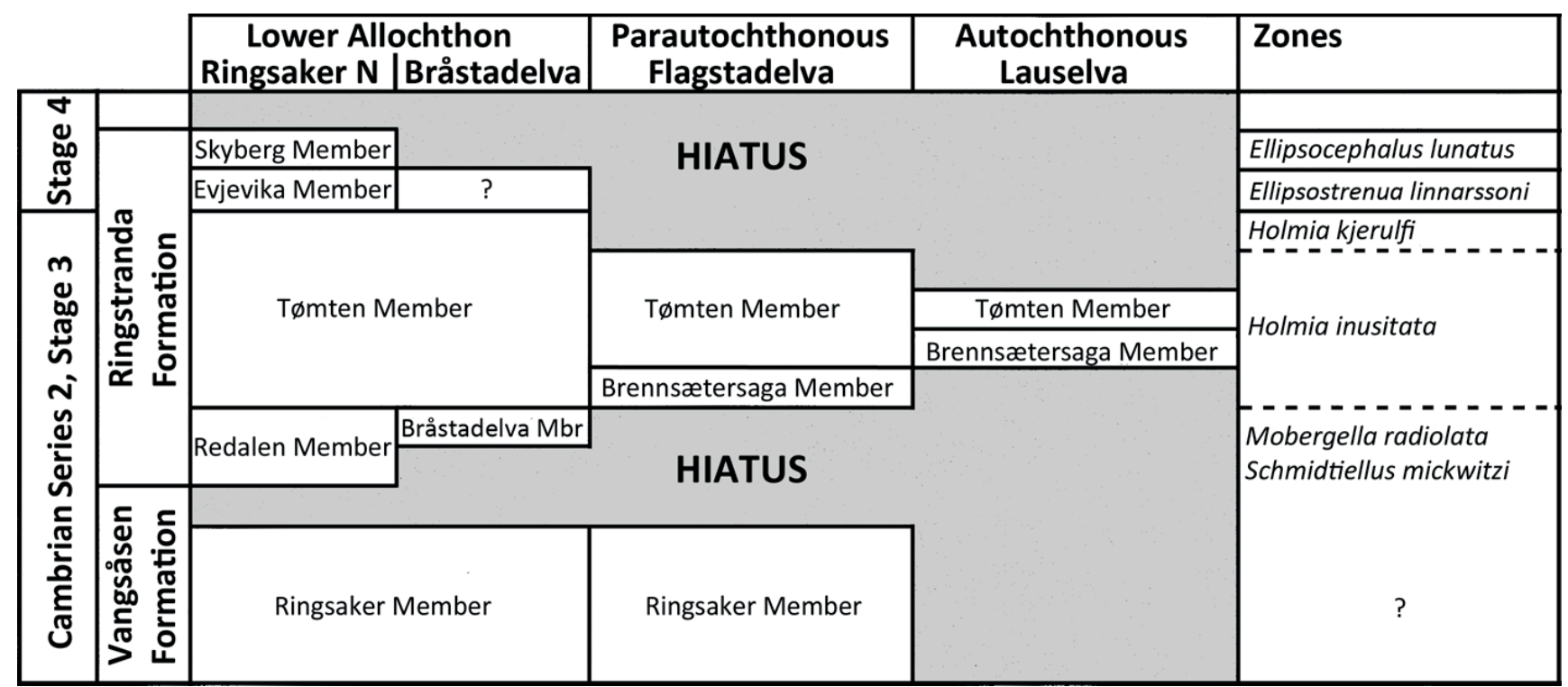

Figure 2. Different tectonostratigraphic settings of the lower Cambrian strata in the Mjøsa area showing formations, members and zonation. Modified from Nielsen \& Schovsbo (2007). 
is used for the entire lower Cambrian fossiliferous strata in older publications. Ebbestad et al. (2003) reverted to the original concept of a discrete $H$. inusitata Zone in their redescription of the trilobite species, based on new specimens.

Nielsen \& Schovsbo (2007) regarded the Holmia inusitata Zone as a local biozone within the Holmia kjerulfi Chronozone and later (Nielsen \& Schovsbo, 2011) proposed abandoning the $H$. inusitata Zone altogether, because it was based on a few specimens recorded solely from the autochthonous Lauselva locality. According to their sequence-stratigraphical correlation, the occurrence of $H$. inusitata is age-equivalent with the Evjevika Member and the Ellipsostrenua linnarssoni Zone.

A few autochthonous sites northeast of the Mjøsa area (Tennåsen, Ena, Kvernbekken and Møra-Andrå) were inferred to be located $60-80 \mathrm{~km}$ farther palaeodownslope from the autochthonous Lauselva locality by Nielsen \& Schovsbo (2011, p. 244) and thus must have been transgressed earlier than the basal layers at Lauselva containing $H$. inusitata. This assumption contributed to the abandoning of the Holmia inusitata Zone (Nielsen \& Schovsbo, 2011). However, according to Skjesth's palaeogeographical reconstruction (1963, plate 2), based on observed stratigraphic units, the sealevel transgressed from the northwest (present-day orientation), with an approximately time-equivalent drowning for the autochthonous outcrops at Lauselva and the sites northeast of the Mjøsa area, resulting in successions of broadly similar age, which undermines the correlation proposed by Nielsen \& Schovsbo (2011, p. 244).

Ahlberg et al. (2016) suggested simplifying the current Cambrian Series 2 stratigraphy with four modified and updated zones, each defined by the first occurrence of the zonal species, the S. mickwitzi, H. kjerulfi, Strenuaeva? spinosa and Chelediscus acifer zones. In this new scenario, the Brennsætersaga Member and the lower part of the Tømten Member (previously termed the Bråstad Shale) containing $H$. inusitata would be within the S. mickwitzi Zone, since the FAD of $H$. kjerulfi, together with the ellipsocephalid Strenuaeva primaeva, a proposed secondary marker for the H. kjerulfi Zone (Ahlberg et al., 2016), is within the upper part of the Tømten Member (previously termed the Holmia Shale).

\section{Stratigraphy of the Flagstadelva section}

The section along the Flagstadelva river (Figs. 1 (locality 1) \& 3), close to the disused and torn-down Brennsætersaga sawmill in the vicinity of the city of Hamar on the east side of Lake Mjøsa, is the stratotype locality for the Brennsætersaga Member of the

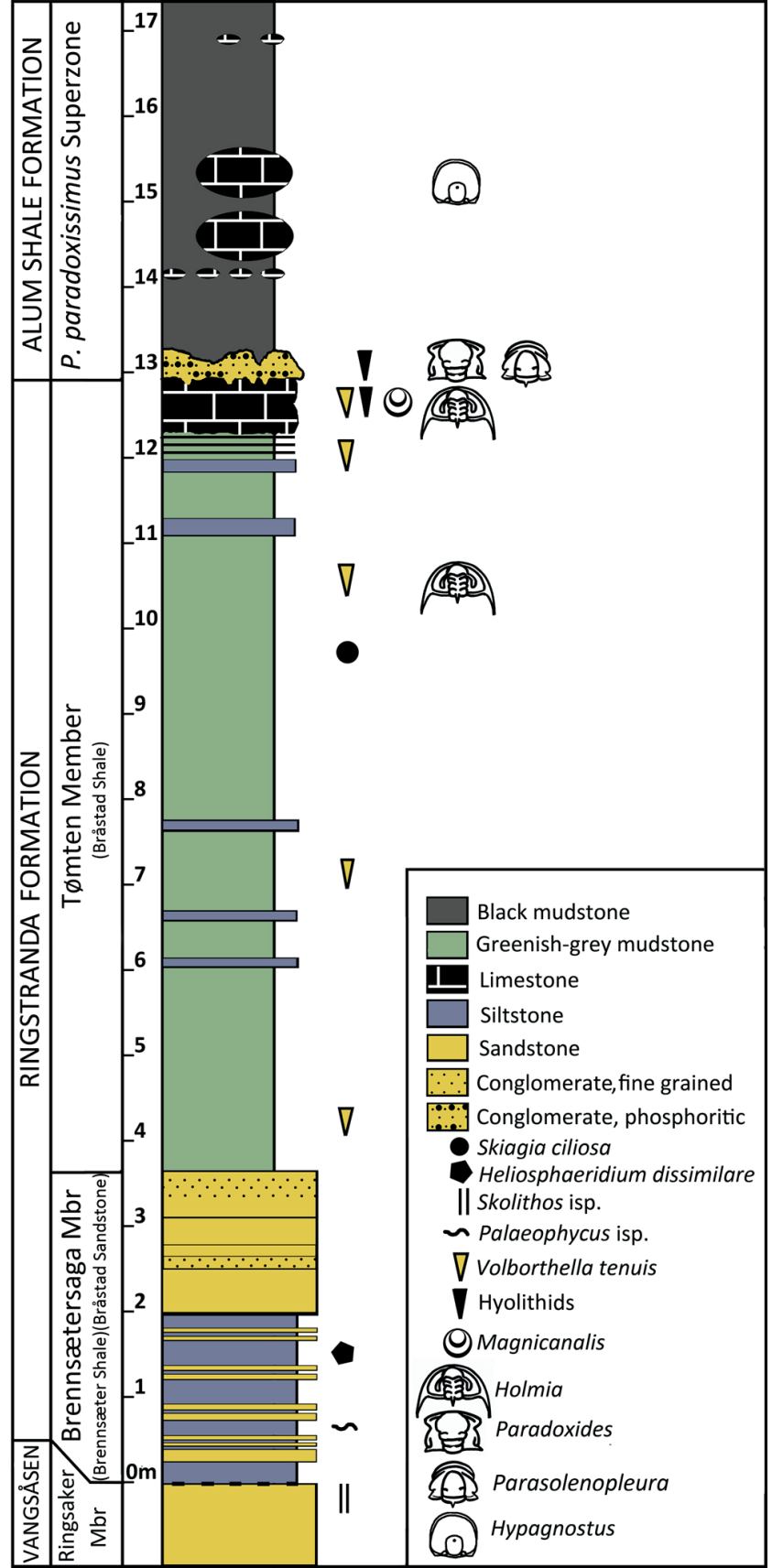

Figure 3. Stratigraphical column of the Flagstadelva river section, close to the disused and torn-down Brennscetersaga sawmill in the vicinity of Hamar on the east side of Lake Mjøsa (WGS 84, 6090162, 1110734). Acritarch data based on Vidal \& Nystuen (1990). Older stratigraphical names are given in parentheses.

Ringstranda Formation (Nielsen \& Schovsbo, 2007). This upward-coarsening member is divided into a c. 2 metre-thick, silty lower part with thin sandstone layers previously referred to as the Brennsæter Limestone, zone $1 \mathrm{aa}$, and a sandstone-conglomeratic unit about $1.5 \mathrm{~m}$ thick in the upper part referred to as the Bråstad Sandstone, zone laa $_{2}$ (Skjeseth, 1963 and Fig. 4). The thin silt- and sandstone layers of the member are 


\begin{tabular}{|c|c|c|c|c|c|c|}
\hline \multicolumn{3}{|c|}{ Skjeseth (1963) } & \multicolumn{2}{|c|}{ Vidal \& Nystuen (1991) } & \multicolumn{2}{|c|}{ Nielsen \& Schovsbo (2007) } \\
\hline \multirow{5}{*}{ 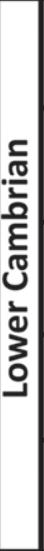 } & $\begin{array}{l}\text { Zone with } \\
\text { Strenuella linnarssoni } \\
\text { and Torellella laevigata }\end{array}$ & $\begin{array}{l}\text { Strenuella } \\
\text { Limestone } \\
1 \mathrm{~b} \beta\end{array}$ & \multirow{6}{*}{ 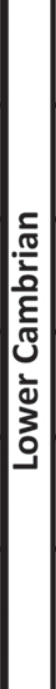 } & Evjevik Limestone & \multirow{5}{*}{ 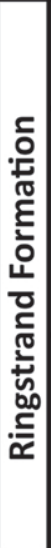 } & Evjevik Member \\
\hline & $\begin{array}{l}\text { Zone with } \\
\text { Holmia kjerulfi }\end{array}$ & $\begin{array}{l}\text { Holmia Shale } \\
1 b \alpha\end{array}$ & & Holmia Shale & & \multirow{2}{*}{ Tømten Member } \\
\hline & $\begin{array}{l}\text { Zone with } \\
\text { Volborthella tenuis } \\
\text { and Callavia n.sp. }\end{array}$ & $\begin{array}{l}\text { Bråstad Shale } \\
1 \mathrm{a} \beta\end{array}$ & & Bråstad Shale & & \\
\hline & $\begin{array}{l}\text { Zone with } \\
\text { Discinella holsti } \\
\text { and Platysolenites } \\
\end{array}$ & $\begin{array}{l}\text { Bråstad } \\
\text { Sandstone } \\
1 \mathrm{a} \alpha 2\end{array}$ & & Bråstad Sandstone & & \multirow{2}{*}{ Brennsætersag Member } \\
\hline & $\begin{array}{l}\text { Zone with } \\
\text { Holmia cf. mickwitzi } \\
\text { and Hyolithus sp. }\end{array}$ & $\begin{array}{l}\text { Brennsæter } \\
\text { Limestone } \\
1 \mathrm{a} \alpha 1\end{array}$ & & Brennsæter Shale & & \\
\hline 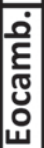 & $\begin{array}{l}\text { Skolithos, } \\
\text { Monocraterion, } \\
\text { Diplocraterion }\end{array}$ & $\begin{array}{l}\text { Ringsaker } \\
\text { Quartzite }\end{array}$ & & $\begin{array}{l}\text { Ringsaker } \\
\text { Quartzite } \\
\text { Member }\end{array}$ & 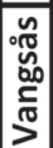 & Ringsaker Member \\
\hline
\end{tabular}

Figure 4. Lithostratigraphic units of the lower Cambrian in the Mjøsa area of Skjeseth (1963), Vidal \& Nystuen (1990) and Nielsen \& Schovsbo (2007). The lowermost Redalen Member and the topmost Skyberg Member of the Ringstranda Formation, present in the Lower Allochthon in the northern part of Lake Mjøsa, are not included in this scheme.

devoid of carbonates, therefore Vidal \& Nystuen (1991, p. 195) re-named it the Brennsæter Shale (Fig. 4). The Brennsætersaga Member is not developed in the most distal Lower Allochthon deposits on the palaeoslope present at Redalen and Ringsaker north (localities 6 and 7 in Fig. 1), but comprises the lowermost member in the Ringstranda Formation in the proximal Caledonian Lower Allochthon deposits at Ringsaker south (locality 8 in Fig. 1), and in the parautochthonous and autochthonous settings (Figs. $2 \& 5$ ).

The stratigraphically overlying Tømten Member of the Ringstranda Formation has traditionally been divided in two units, the Bråstad Shale and the Holmia shale, until Nielsen \& Schovsbo (2007) defined them as one, lithologically fining-upward sequence (Fig. 4). At Flagstadelva, c. $9 \mathrm{~m}$ of greenish-grey mudstone and siltstone of the lower part of the Tømten Member (previously named Bråstad Shale) is preserved.

The top of the Tømten Member at Flagstadelva is developed as a $30-50 \mathrm{~cm}$-thick limestone bed with an erosional contact to a 10-30 cm-thick phosphoritebearing conglomerate. The conglomerate is the base of the Alum Shale Formation at this locality, which otherwise is represented here by a few metres of dark shales with limestone nodules. Both the limestone and the conglomerate interval was earlier referred to as the 'Ölandicus-conglomerate' (Skjeseth, 1963).

The Ringstranda Formation rests unconformably on the Ringsaker Member of the Cambrian Vangsåsen Formation in the Lower Allochthon and parautochthonous settings (Fig. 2). Skolithos- and Diplocrateriontype trace fossils occur at the very top of the Ringsaker
Member in the parautochthonous setting, with the former type present at Flagstadelva and Sollerud (localities $1 \& 2$ in Fig. 1), and both types are present at Langodden (locality 3 in Fig. 1).

In the Flagstadelva section, the dip is close to $90^{\circ}$ and the Brennsætersaga Member is weakly folded in a tectonic contact with the massive quartzite of the Ringsaker Member, but the repetition reported by Daily (1972) was not recognised by the present authors (see also Føyn \& Glaessner, 1979, p. 41).

The Bråstad Sandstone of older literature was first described from the Caledonian Lower Allochthon along the River Bråstadelva (locality 9 in Fig. 1) on the west side of Lake Mjøsa (Bråstad, 1915). These beds cannot be correlated with the parautochthonous Brennsætersaga Member in a consistent way and are inferred to be older than the Brennsætersaga Member in the Flagstadelva section (Nielsen \& Schovsbo, 2007, p. 67, fig. 8; 2011, fig. 27). The diachronous transgression from the northwest (present-day orientation) resulted in older deposits in the distal Lower Allochthon than in the more proximal parautochthonous area in the southeast (Fig. 5). This is corroborated by finds of Mobergella radiolata Bengtson and M. holsti Moberg at the Bråstadelva locality (pers. obs. MH; see discussion below), here considered the oldest macrofossils in the Mjøsa area (Fig. 6). Nielsen \& Schovsbo $(2007,2011)$ interpreted the basal layers at Bråstadelva to be the most distally deposited unit, but we follow Skjeseth's (1963, fig. 18) interpretation in considering the northernmost localities at Ringsaker and Redalen to be the most distal deposits on the palaeoslope. 


\section{Resolving the fossil occurrences in the Flagstadelva section}

New research spanning the entire river section, including the Brennsætersaga Member, the stratigraphically overlying Tømten Member (Bråstad Shale in previous term) and the 'Ölandicus-conglomerate', has resulted in numerous new specimens of an olenellid trilobite that is described herein. The lithology of the new material is comparable to the matrix of Skjeseth's specimen of $H$. cf. mobergi, consisting of pyrite-impregnated silty limestone, but was collected in situ from a thin silty limestone facies in the uppermost few centimetres of the previously termed Bråstad Shale at $12.5 \mathrm{~m}$ in the section in direct contact with the supposed middle Cambrian 'Ölandicus-conglomerate' of Skjeseth (1963) (Fig. 3). Except for some undeterminable olenellid remains found in the mudstone at $10.5 \mathrm{~m}$ in the section, this is the only reliable occurrence of olenellids here. Therefore, the position of the single trilobite find of Skjeseth seems to be misplaced, as the lower part of the section has proved to be barren of shelly fossils despite more than 50 years of search; moreover, the lower part of the section does not contain carbonates.

Skjeseth (1963) also reported the occurrence of Discinella (= Mobergella), an enigmatic but potentially important fossil for biostratigraphy, from a thin sandstone bed in zone $1 \mathrm{aa}_{2}$, the upper part of the Brennsætersaga Member (formerly the Bråstad Sandstone) in the Flagstadelva river section. These specimens have not been located in the collections of the Natural History Museum in Oslo, Norway, where other samples from Skjeseth's research are housed, nor has the record been confirmed during the numerous later examinations of the section listed above. Mobergella-bearing sandstones in Scandinavia correlate with the lower part of the Heliosphaeridium dissimilare-Skiagia ciliosa acritarch Zone (Moczydłowska, 1991), stratigraphically above the S. mickwitzi Zone. On the Siberian Platform, Mobergella radiolata Bengtson (also occurring at the Bråstadelva locality, pers. obs. $\mathrm{MH}$ ), is found in older deposits of early Atdabanian age (e.g., Demidenko, 2016; Zhang et al., 2017) corresponding to the Schmidtiellus mickwitzi Zone and older age. In earlier publications, prior to the acritarch zonation, Mobergella-bearing units have traditionally been considered S. mickwitzi Zone in age (e.g., Mens et al., 1990). Considering Skjesth's erroneous placement of $H$. cf. mobergi, the extensive examinations of the section throughout the years and the lack of material in the collections of the Natural History Museum, Oslo, the recorded occurrence of mobergellans in the Brennsætersaga Member at Flagstadelva should be treated with caution and is most likely erroneous.

The 50-70 cm-thick bed capping the Bråstad Shale at Flagstadelva has been referred to the middle Cambrian 'Ölandicus-conglomerate' (Skjeseth, 1963), but only the uppermost few centimetres of this bed at approximately $13 \mathrm{~m}$ in the section consists of small, well-rounded quartz and phosphorite grains with sporadic coarser-grained pebbles up to $20 \mathrm{~mm}$ in diameter (Fig. 3). This thin conglomerate forms the base of the middle Cambrian at this locality. The olenellid-containing calcareous lower part of this bed and the conglomerate at the top of the bed are sharply divided by an erosional surface (Fig. 7A) representing a considerable time-span. Commonly occurring trilobite sclerites in the conglomerate belong to the mid-Cambrian trilobites Paradoxides paradoxissimus (Wahlenberg) and Parasolenopleura spinigera Westergård (Fig. 7B-F), indicating the Ptychagnostus atavus Zone or the Ptychagnostus punctuosus Zone. Hypagnostus parvifrons Linnarsson, a common taxon in both agnostoid zones, was collected $2 \mathrm{~m}$ above the conglomerate. The transgression event following the Hawke Bay unconformity resulted in the earliest deposits distally in the Caledonian Lower Allochthon in mid-Cambrian times. Hence, sediments of the Acadoparadoxides oelandicus Superzone are found only in the Caledonian Lower Allochthon strata in the Miøsa area (Høyberget \& Bruton, 2008). Areas in the parautochthonous and autochthonous settings were flooded during the much younger Ptychagnostus atavus Zone in the Paradoxides paradoxissimus Superzone, based on fossil occurrences at Risbekken (Høyberget \& Bruton, 2008) (locality 4 in Fig. 1) and Flagstadelva.

Skjeseth (1963, p. 41) refers to worm tracks in the Brennsætersaga Member in the Flagstadelva section as being similar to those found in abundance in the stratigraphically older Redalen Member, but few ichnospecies have been observed during recent investigations, only some simple Palaeophycus-type burrows. The Redalen Member in the Caledonian Lower Allochthon setting though yields a range of significant trace fossils in addition to Palaeophycus isp. (see below).

Vogt (1924) reported two small fragments (0.7 and 1.5 $\mathrm{mm}$ long, respectively) of Platysolenites antiquissimus Eichwald from the Lower Allochthon Redalen Member, which was correlated with the Bråstad Sandstone in Flagstadelva by Skjeseth (1963). Some attention has been paid to this specious correlation in later publications (e.g., Hamar, 1967; Martinsson, 1974; Føyn \& Glaessner, 1977; Bergström, 1981). The tubular P. antiquissimus is an index fossil for considerably older Terreneuvian strata and the occurrence of this taxon in the presumed much younger Redalen Member has not been re-confirmed, nor has it been found in the Flagstadelva section; therefore, its presence in the Ringstranda Formation is considered highly dubious. 


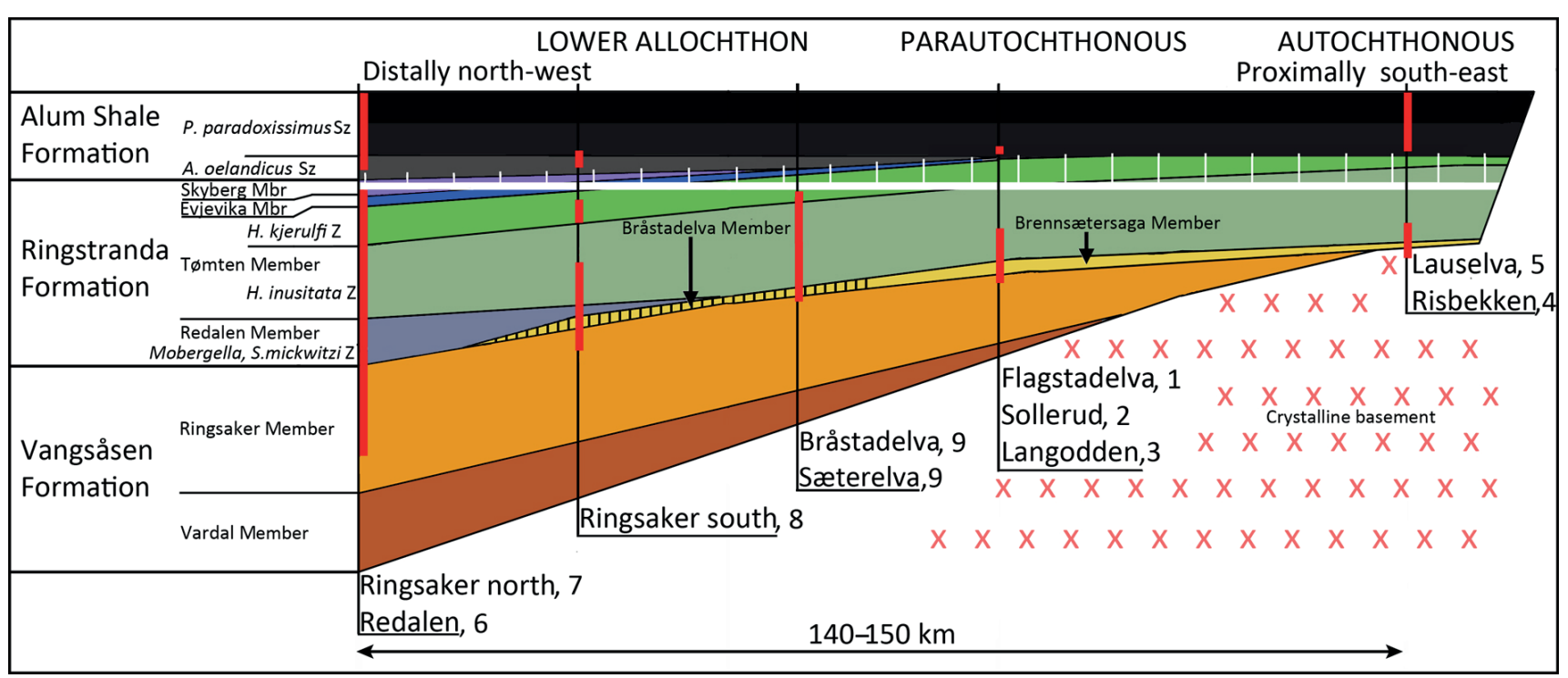

Figure 5. Correlation scheme of the different tectonostratigraphic settings in the Mjøsa area showing lithostratigraphy, zonation and important lower Cambrian outcrops. The numbers by each outcrop name correspond to their position on the map in Fig. 1. The white, hachured line indicates the Hawke Bay unconformity and possible denudation. Red bars indicate preserved sections at the different outcrops.

\section{Implications for the lower Cambrian stratigraphy in the Miøsa area}

Early research on acritarch biostratigraphy of the lower Cambrian strata in Scandinavia (Vidal, 1981a, b; Moczydłowska \& Vidal, 1986) suggested an age correlative to the Lükati Beds of the East European Platform (EEP) for the laa zone in the Mjøsa area (= the Brennsætersaga Member). This age is equivalent to the S. mickwitzi Zone. A later publication on acritarchs from the Mjøsa area, including the Flagstadelva river section (Vidal \& Nystuen, 1990), showed all recorded species from the Brennsætersaga Member to be longranging and biostratigraphically undiagnostic common elements in the S. mickwitzi Zone or older deposits, except for a single species: Heliosphaeridium dissimilare (Volkova). The age of the lowermost unit at Flagstadelva was therefore considered ambiguous but correlative with the Vergale Beds in the EEP, which is age equivalent to the Holmia kjerulfi Assemblage Zone. This new proposal was based on scarce material counting only 1 or 2 recorded specimens of $H$. dissimilare, the only age-diagnostic acritarch species from the unit (Vidal \& Nystuen, 1990 fig. 6, and Fig. 3 herein). This indicated a younger age of Holmia cf. mobergi than had previously been suggested, a conclusion followed by Moczydłowska (1991, 2002) based on the same scarce acritarch samples. However, this acritarch species' age-diagnostic reliability is questioned by its early occurrences outside Baltoscandia (e.g., Vidal et al., 1994; Jensen et al., 2010). The age-diagnostic acritarch species Skiagia ciliosa is found in close proximity to the new olenellid material in the overlying Tømten Member (previously the Bråstad Shale) at Flagstadelva (Vidal \& Nystuen, 1990, see also
Fig. 3). These two taxa provided an age-constrain to the Heliosphaeridium dissimilare-Skiagia ciliosa Zone as presently understood (e.g., Moczydłowska, 1991, 2002), which is equivalent to the Holmia inusitata and Holmia kjerulfi trilobite zones (Holmia kjerulfi Assemblage Zone) of the Tømten Member. Therefore, there is no evidence of fossil-bearing deposits of the Schmidtiellus mickwitzi trilobite zone in the parautochthonous Mjøsa area (Fig. 2).

The Caledonian Lower Allochthon setting of the Bråstad Sandstone at Bråstadelva (locality 9 in Fig. 1) was referred to as the Cambrian basal unit with Discinella holsti by Vogt (1924), and mobergellans are known in abundance in a thin, 5 cm-thick layer (Bråstad, 1915; Vogt, 1924; Skjeseth, 1963) (counting 150 specimens in the collections of the Natural History Museum, Oslo). The Bråstad Sandstone in the Bråstadelva section is here considered time-equivalent to the upper part of the more distally deposited Redalen Member (Fig. 2 \& 5) and not equivalent to the upper part of the Brennsætersaga Member as perceived earlier, and is here informally named the Bråstadelva member. The Redalen Member and the Brasstadelva member in the Ringstranda Formation are both confined to Lower Allochthon strata and thereby within the same tectonostratigraphic setting.

The Bråstadelva member and the Redalen Member at Redalen and Ringsaker (localities 6-9 in Fig. 1), may be referred to the S. mickwitzi Zone. The Redalen Member is rich in trace fossils and the very common and distinct Palaeophychus isp. nov. and the rare Cheiichnus isp. are also recorded from the lower part of the Grammajukku Formation at Storuman, Sweden, occurring within the $S$. mickwitzi Zone (Moczydłowska et al., 2001). Gyrolithes 
isp. and Phycodes palmatus from the Redalen Member are, in common with occurrences from the Såvvovare Formation in Laisvall, southern Swedish Lapland, interpreted to be within the Terreneuvian Platysolenites antiquissimus Zone (Moczydłowska et al., 2001) and are also described from the lower part of the Torneträsk Formation at Luovárri in northern Sweden within the Platysolenites antiquissimus Zone (Jensen \& Grant, 1998). Both ichnospecies are long-ranging.

The Tømten Member is only $9 \mathrm{~m}$ thick in the parautochthonous Flagstadelva section and close to $50 \mathrm{~m}$ thick in the Lower Allochthon on the west side of Lake Mjøsa, a thickness that may well be underestimated (Bjørlykke, 1979). Several metres of the fossil-rich greenish mudstone in the upper part of the Tømten Member, traditionally termed the Holmia Shale, were eroded during the Hawke Bay regression event, or alternatively were not deposited (Fig. 5). The Hawke Bay unconformity is thus significantly more extensive in the parautochthonous strata than in the Lower Allochthon, as already suggested by Nielsen \& Schovsbo (2011, p. 244, 2015, p. 315). Consequently, only the lower part of the Tømten Member (previously the Bråstad Shale) is preserved in the Flagstadelva river section (Fig. 5). The absence of the traditionally termed Holmia Shale (now upper part of the Tømten Member) and the overlying Strenuella Limestone (= Evjevika Member) in the Flagstadelva river section was emphasised by both Skjeseth (1963) and Yochelson et al. (1977). In the Lower Allochthon Bråstadelva section, the thickness of the previously termed Bråstad Shale is difficult to measure due to complex tectonics and repetition of strata, but is estimated to exceed 20-30 metres (Bjørlykke, 1979).

\section{The Holmia inusitata Zone}

In the Lower Allochthon, and also in parautochthonous and autochthonous strata on the west and east side of Lake Mjøsa, the alternating mudstone and siltstone facies in the lower part of the Tømten Member contain a low-diversity fossil assemblage, in striking contrast to the younger beds. A single trilobite taxon, Holmia inusitata Ahlberg \& Bergström, scattered finds of the brachiopod Magnicanalis Rowell, the tubular Torellella Holm and very common occurrences of the agglutinated, enigmatic Volborthella Schmidt are the only recorded macrofossils (Fig. 6). The fine-grained mudstone of the upper part of the Tømten Member (the Holmia Shale in older terms), however, yields a remarkably more diverse fauna, counting three trilobite families represented by at least eight species including the first appearance of ellipsocephalids, several hyolith- and brachiopod taxa and enigmatic, tubular fossils (Kiær, 1917 and personal observations; Fig. 6). This radiation is also reflected in the significant increase in the diversity of acritarch species in the Holmia Shale (Vidal \& MoczydłowskaVidal, 1997; Moczydłowska, 2002). The fossil content is further diversified with an increase in number of animal groups and species in the overlying Evjevika Member (Høyberget et al., 2015) and unpublished material from the Skyberg Member, both Series 2, Stage 4 in the Ringstranda Formation. This rather sudden faunal diversity in Holmia kjerulfi-age sediments and the flourish of ellipsocephalids contrast the low diversity in the older Bråstad Shale, which strengthens the validity of a Holmia inusitata Zone at least as a local biozone in the Mjøsa area.

Further research may confirm the Holmia inusitata Zone elsewhere in Scandinavia and closer attention should be paid to the interesting finds of Holmia sp. described from the Grammajukku Formation at Storuman in southern Swedish Lapland (Moczydłowska et al., 2001). Lower Cambrian strata are preserved in a $2000 \mathrm{~km}$-long autochthonous unit following the Caledonian nappe front in Scandinavia up to Finnmark in the far north of Norway (Føyn \& Glaessner, 1979). A few places have been investigated, but vast areas remain unknown.

Some rare olenellid material collected from the Digermulen Peninsula in northernmost Norway by Henningsmoen \& Nikolaisen in the early 1960s, were interpreted as conspecific with Holmia cf. mobergi by Bergström (1980). The olenellid-bearing strata on the Digermulen Peninsula were subsequently considered

\begin{tabular}{|c|c|c|c|c|c|c|c|c|}
\hline ZONES & \multicolumn{7}{|c|}{ BIOTA } & COUNTS \\
\hline E. lunatus & $\begin{array}{l}\begin{array}{l}\text { eeee } \\
\text { bbb }\end{array} \\
\end{array}$ & \begin{tabular}{|l} 
M \\
B \\
phphph
\end{tabular} & hyhyhy & $x$ & & $\begin{array}{l}\text { V } \\
\text { II } \\
\text { Hyo } \\
\text { tutututu }\end{array}$ & $x$ & 26 \\
\hline E. linnarssoni & \begin{tabular}{|l} 
ooo \\
eeeeee \\
Eo \\
$b$
\end{tabular} & $\begin{array}{l}\mathrm{M} \\
\mathrm{B} \\
\mathrm{ph}\end{array}$ & $\begin{array}{l}\text { hehehehehe } \\
\text { hy }\end{array}$ & $x$ & & & & 21 \\
\hline H. kjerulfi & \begin{tabular}{|l|}
0000 \\
eee \\
Eo \\
\end{tabular} & $\begin{array}{l}\mathrm{M} \\
\mathrm{B} \\
\mathrm{ph}\end{array}$ & hyhy & $\bar{x}$ & & $\begin{array}{l} \\
\\
\\
\text { Hyo } \\
\text { tutu } \\
\text { tutu }\end{array}$ & $x$ & 20 \\
\hline H. inusitata & 0 & $M$ & hy & & & $\begin{array}{l}\text { V } \\
\text { T } \\
\text { tu }\end{array}$ & $\mathrm{X}$ & 7 \\
\hline \multirow[t]{2}{*}{$\begin{array}{l}\text { Mobergella, } \\
\text { S. mickwitzi } \\
\end{array}$} & & & & & & $\mathrm{mm}$ & & 2 \\
\hline & 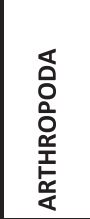 & 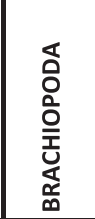 & 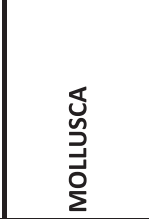 & 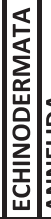 & & 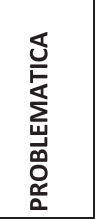 & & \\
\hline
\end{tabular}

Figure 6. Fossil content recorded from the biostratigraphical zonation adopted in this paper: $o$ - olenellids, $e$-ellipsocephalids, Eo - eodiscids, $b$ - bradoriids, $M$ - Magnicanalis, $B$ - Botsfordia, ph - phosphatic brachiopods, hy - hyolithids, he - helcionellids, $V$ - Volborthella, T - Torellella, Hyo - hyolithelminthids, $l$ lapworthellids, tu - tubular fossils, $m$ - mobergellans, $X$ - present. Each abbreviation indicates one species. Based on Kior (1917), Høyberget et al. (2015) and unpublished data. 
Schmidtiellus mickwitzi Zone in age in later publications (Bergström, 1981; Ahlberg, 1984, 1985; Ahlberg et al., 1986; Moczydłowska, 1991, 2002; Jensen \& Grant, 1998). Extensive new studies yielding acritarchs and a rich collection of trilobites here (Palacios et al., 2015; Ebbestad et al., 2017), including ellipsocephalids (personal observations), have shown that the olenellidbearing strata in this northernmost area of the Caledonides occur within the $H$. dissimilare-S. ciliosa Zone and confirming Nikolaisen \& Henningsmoen's (1987) assignment of their scarce Digermulen Peninsula material to the trilobite genus Kjerulfia Kiær.

\section{Systematic palaeontolgy}

Specimens of Hyolithus sp. and Obolella sp., previously reported by Skjeseth (1963, p. 48) to co-occur with Holmia cf. mobergi, were not found in the collections of the Natural History Museum, Oslo, but during recent investigations of the section a single hyolithid shell and a single, damaged, brachiopod specimen were collected together with the new Holmia material (Figs. 3 \& 7G, H). The hyolithid is collapsed and the shell is mostly peeled off. Shell ornamentation is therefore not preserved. The specimen is $15 \mathrm{~mm}$ long and weakly curved, and the internal mould is $1.5 \mathrm{~mm}$ across at the widest end. A small preserved shell patch shows a thickness of $\sim 0.2$ $\mathrm{mm}$. This specimen is interpreted as a hyolith and not a trilobite genal spine because of the calcite-crystalline wall of the shell patch, quite unlike the trilobite preservation from this locality.

A damaged specimen identified as the brachiopod Magnicanalis Rowell (Fig. 7H), previously placed with Obolella (e.g., Kiær, 1917), was collected from the silty limestone. The pattern of the growth lines is very similar to $M$. rotundata (Kiær), which commonly occurs in the overlying $H$. kjerulfi Zone and abundantly in the younger Ellipsostrenua linnarssoni Zone (Høyberget et al., 2015).

The enigmatic, cone-shaped and agglutinated Volborthella Schmidt is repeatedly cited in publications on the Cambrian stratigraphy of the Mjøsa area and figured and described by Bråstad (1915), Kiær (1917) and more thoroughly by Yochelson et al. (1977) from the Bråstad Shale $(=H$. inusitata Zone) and also from the Holmia Shale (= H. kjerulfi Zone) by Kiær (1917). The latter occurrence was not confirmed by Yochelson et al. (1977), who confined Volborthella to the Bråstad Shale only. Attempts have been made to establish a zone with Volborthella tenuis Schmidt as the eponymous species (e.g., Vogt, 1924; Skjeseth, 1963). The taxon, though, is long ranging and found throughout the Tømten and Skyberg members of the Ringstranda Formation (unpublished personal observations $\mathrm{MH}$ ) and is probably of little biostratigraphic value. Volborthella is very common, in places occurring in clusters in the lower part of the Tømten Member (Bråstad Shale), and has been collected throughout this unit in the Flagstadelva river section. The conical specimens show a considerable variation in divergence of the outer margins from the apex to the widest end (Fig. $7 \mathrm{~L}, \mathrm{M}$ ), from $26^{\circ}$ to $12^{\circ}$ and with most specimens around $17^{\circ}$. The length/width ratio varies between 2.3 and 5.3 and is around 3.6 in most specimens. Volborthella is by far the most common fossil in the Holmia inusitata Zone and is reported from a large number of outcrops in the Mjøsa area. Specimens from Flagstadelva and Lauselva are here figured for the first time (Fig. 7I-M).

\section{Material and methods}

We provide here the correct spellings of the Lower Cambrian Norwegian members and formations. The new spellings are in grammatical accordance with the formally described Norwegian Ordovician and Silurian members and formations (Worsley et al., 1983; Owen et al., 1990).

Linear measurements used in this analysis are explained in Fig. 8A.

Bivariate and ordination analyses were undertaken on linear measurements made on suitable material. All measurements were done on images of specimens in Adobe Photoshop. Statistical tests and the PCA analyses were performed with Microsoft Excel and the statistical package PAST, version 3.10 (Hammer et al., 2001).

A new figure of the original specimen (PMO 113.235) collected by Skjeseth (Fig. 9A) is presented and additional material from the Flagstadelva river section is provided, collected during investigations in 2002-2005. This new material consists of partially preserved cephala, including a series of six meraspid (PMO 234.265-PMO 234.268/1, PMO 234.269 and PMO 234.270/1) and twelve holaspid cephala (PMO 234.268/3 with counterparts PMO 234.268/3A and B showing the entire length of the occipital spine, PMO 234.270/2, PMO 234.271, PMO 234.272/1, PMO 234.272/2, PMO 234.273/1, PMO 234.273/2, PMO 234.274-PMO 234.278) of different size, four hypostomes (PMO 234.268/2, PMO 234.279-PMO 234.281), nine articulated thoracic segments (PMO 234.282) with a macrospine on the $9^{\text {th }}$ segment, four isolated thoracic segments (PMO 234.283-PMO 234.286), one genal spine with inner spine angle and counterpart (PMO 234.306) and one pygidium (PMO 234.287), all collected at about $12.5 \mathrm{~m}$ in the Flagstadelva river section.

Additional well-preserved topotype material of $H$. inusitata was collected from Lauselva between the 1.5 and $2.0 \mathrm{~m}$ levels in the section (see Ebbestad et al., 2003, text 

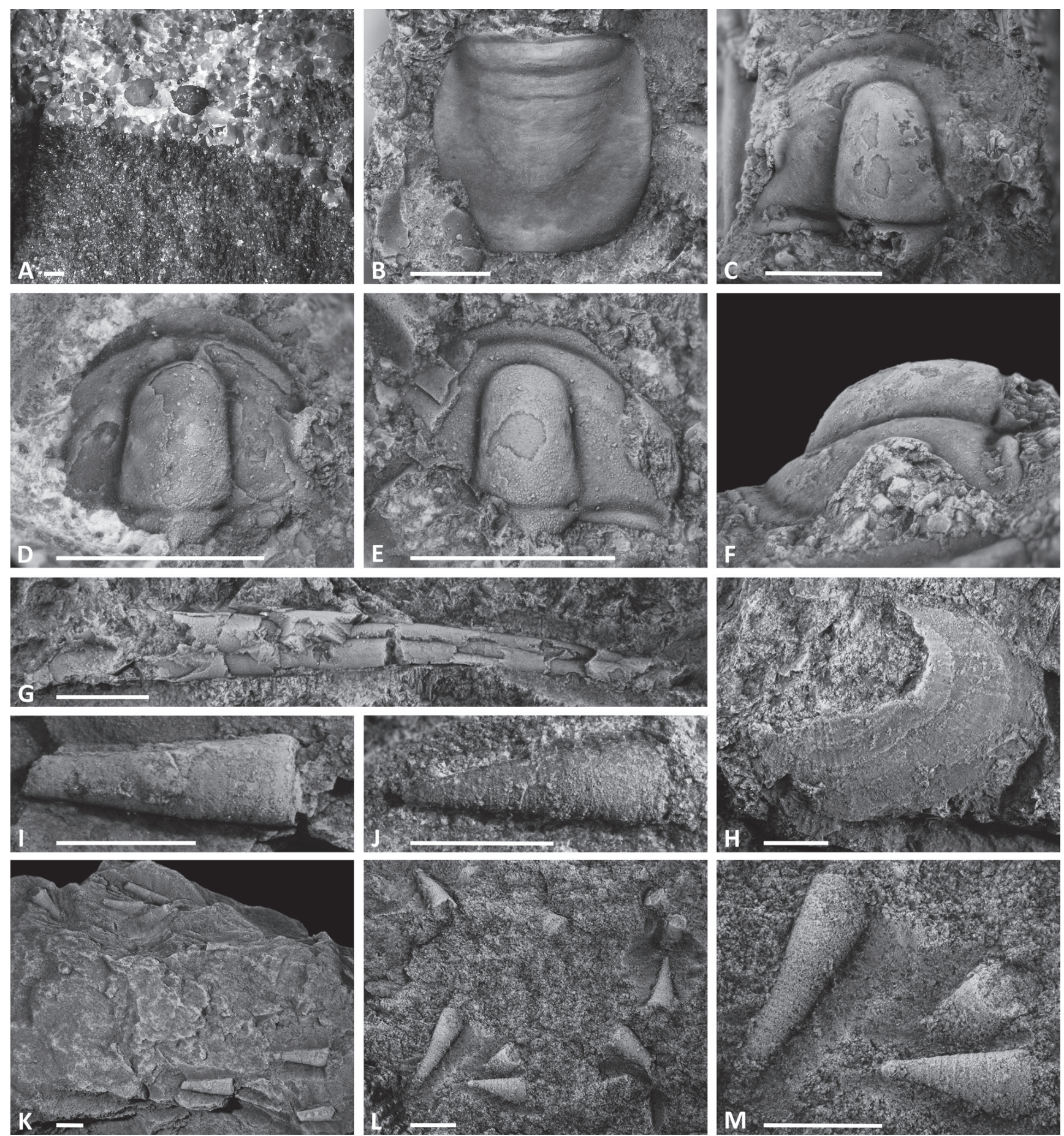

Figure 7. (A) Photo showing the sharp erosive surface between the mid-Cambrian basal conglomerate of the Alum Shale Formation with calcite-cemented, rounded, quartz- and phosphorite grains and the lower Cambrian silty limestone of the Tomten Member, containing Holmia inusitata. 13 m level, Flagstadelva. (B) Pygidium of Paradoxides paradoxissimus (PMO 234.299/1). (C, F) Parasolenopleura spinigera (PMO 234.300/1). (D) Parasolenopleura spinigera, note occipital spine (PMO 234.300/2). (E) Parasolenopleura spinigera (PMO 234.299/2). B-F from basal conglomerate of the Alum Shale Formation, Flagstadelva. (G) Hyolithid (PMO 234.301), Tømten Member, $12.5 \mathrm{~m}$ level, Flagstadelva. (H) Magnicanalis sp. (PMO 234.270/3), Tømten Member, $12.5 \mathrm{~m}$ level. Flagstadelva. (I) Volborthella, same slab as K. (J) Volborthella (PMO 234.303), Tømten Member, $12 \mathrm{~m}$ level, Flagstadelva. (K) Cluster of Volborthella (PMO 234.302), Holmia inusitata Zone. Lauselva. (L, M)

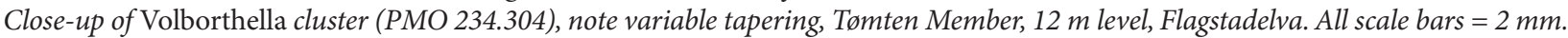

fig. 3) during investigations in 2000-2009. This consists of three nearly complete specimens (PMO 234.288PMO 234.290), one showing an in situ hypostome and pygidium, one fragmentary cephalon with five attached thoracic segments (PMO 234.291), four partially preserved cephala (PMO 234.292-PMO 234.295), one fragmentary cephalon with hypostome attached (PMO 234.296), two articulated thoracic regions, one with 7 segments (PMO 234.297), another with 9 segments (PMO 234.305), both specimens carrying a macrospine 

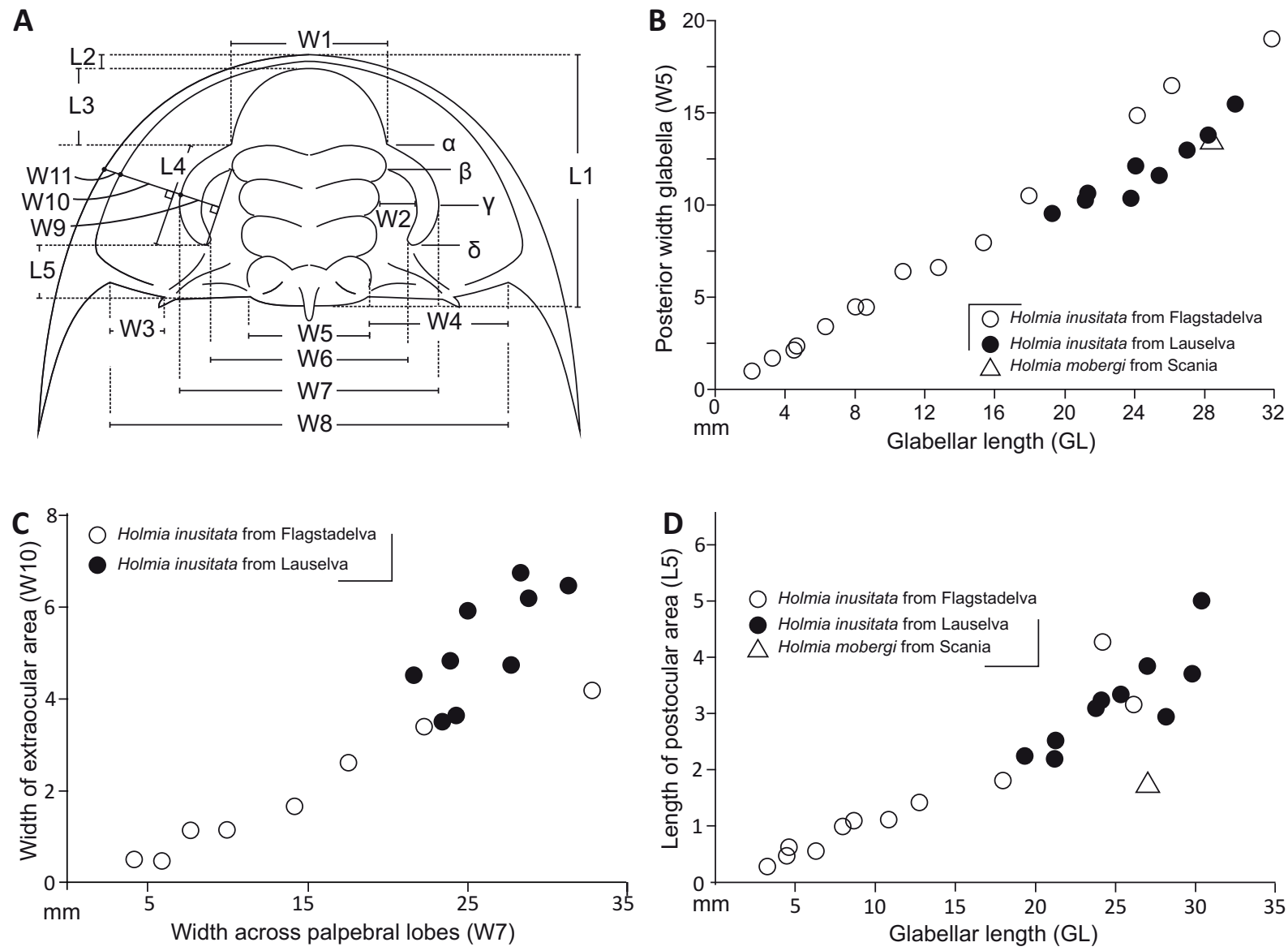

E

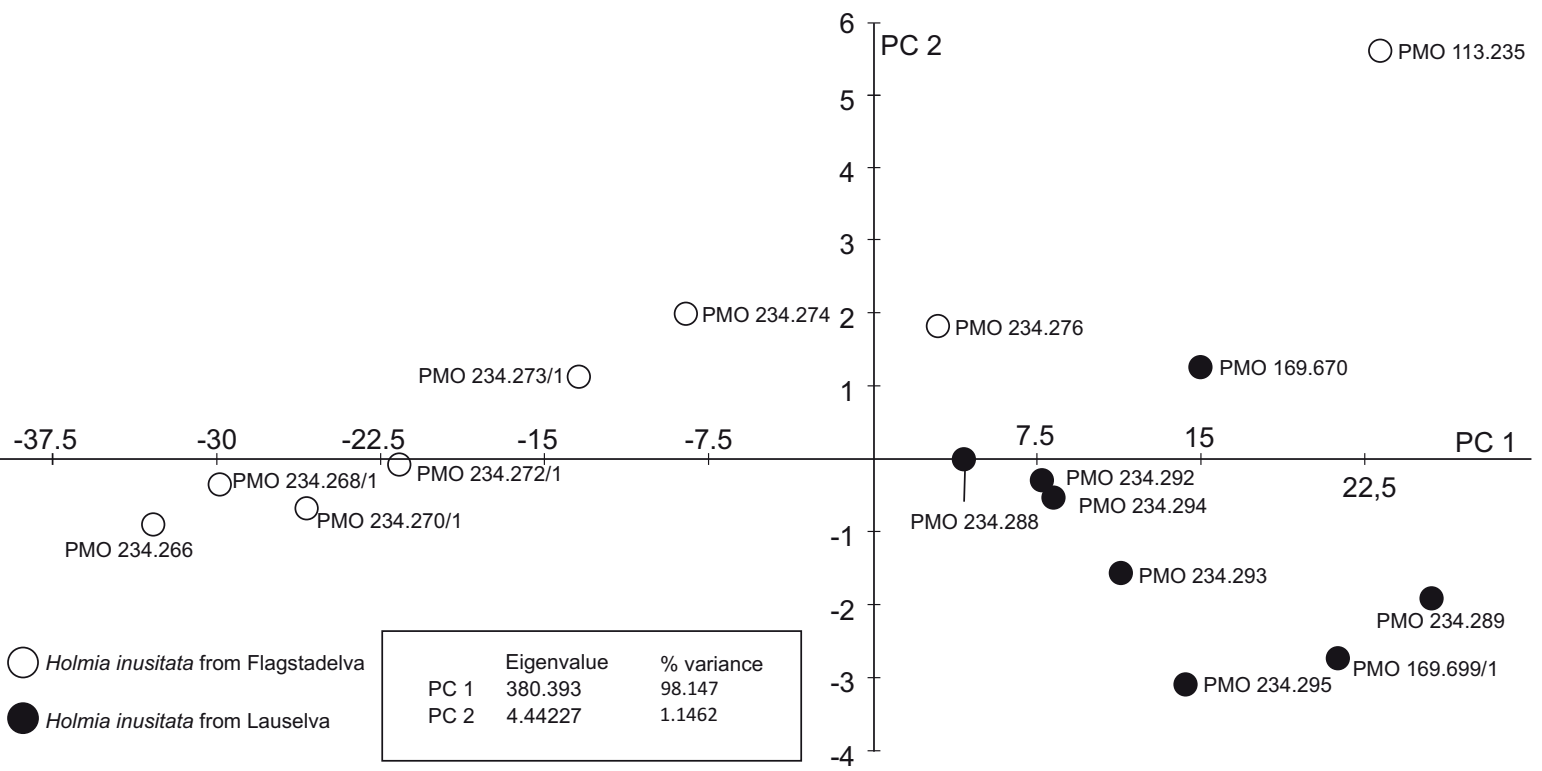

Figure 8. (A) Schematic drawing of the cephalon of $\mathrm{H}$. inusitata with the linear measurements used in this analysis. (B) Bivariate plot of glabellar length (GL) against posterior width of the glabella (W5). (C) Bivariate plot of the width across the palpebral lobes (W7) against width of the extraocular area (W10). (D) Bivariate plot of glabellar length (GL) against length of the postocular area (L5). (E) Scatter plot of the PCA analysis.

on the $9^{\text {th }}$ segment, and one partial thoracic segment (PMO 234.298).
The material described or discussed in this paper is housed at the Natural History Museum in Oslo, Norway (PMO), Swedish Geological Survey, Sweden (SGU), Lund University, Sweden (LO) and the Museum of Evolution, Uppsala University, Sweden (PMU). 
Suborder Olenellina Walcott, 1890

Family Holmiidae Hupé, 1953

\section{Genus Holmia Matthew, 1890}

Type species: By original designation of Matthew (1890, p. 160), Paradoxides kjerulfi Linnarsson, 1871, p. 790, from the lower Cambrian Tømten Member of the Ringstrand Formation (previously the Holmia Shale) at Stein in the Ringsaker district, Norway.

Holmia inusitata Ahlberg \& Bergström, in Ahlberg et al., 1986

Figs. 9-19

1956 Holmia cf. mickwitzi (Schmidt) - Henningsmoen (biostratigraphic scheme and listed in the text).

1960 Holmia cf. mickwitzi (Schmidt) - Henningsmoen (biostratigraphic scheme and listed in the text).

1963 Holmia cf. mickwitzi (Schmidt) - Skjeseth (mentioned in text and lithostratigraphic column).

1963 Callavia sp. n. - Skjeseth (mentioned in text and lithostratigraphic column).

1974 Schmidtiellus cf. mickwitzi (Schmidt) - Martinsson (discussion and table with Scandinavian biozones).

1974 Callavia n. sp. Skjeseth - Martinsson (mentioned in the text).

1977 Schmidtiellus cf. mickwitzi (Schmidt) - Bengtson (mentioned in the text).

1978 Holmia cf. mobergi Bergström - Ahlberg \& Bergström (table with biozones).

1978 Holmia n. sp. Ahlberg \& Bergström (table with biozones).

1979 Holmia cf. mickwitzi (Schmidt) - Føyn \& Glaessner (listed in the text).

1980 Holmia mobergi Bergström - Bergström (listed in the text).

1980 Holmia n. sp. - Bergström (biostratigraphic scheme and listed in the text).

1981 Holmia mobergi(?) Bergström [part.] - Bergström (listed in the text and Baltoscandian correlation chart). Not material from Finnmark $=$ Kjerulfia $n$. sp.

1981 Holmia n. sp. ("Callavia") Bergström (listed in the text).

1981 Holmia n. sp. Bergström - Bergström \& Ahlberg (correlation scheme).

1981a Holmia cf. mobergi Bergström - Vidal (mentioned in the text).

1981bHolmia n. sp. Bergström - Vidal (mentioned).

1984 Holmia cf. mobergi Bergström - Ahlberg (mentioned).

1984 Holmia n. sp. Bergström - Ahlberg (mentioned).

1985 Holmia cf. mobergi Bergström - Bergström \& Gee (listed in the text).

1985 Holmia cf. mobergi Bergström - Ahlberg (mentioned in the text and biostratigraphic scheme).
1985 Holmia n. sp. Bergström - Ahlberg (mentioned in the text and biostratigraphic scheme).

1986 Holmia inusitata n. sp. - Ahlberg \& Bergström (description and fig. 3).

1986 Holmia cf. mobergi Bergström [part.] - Ahlberg et al. (description and fig. 6). Not fig. 8A, B from Finnmark = Kjerulfia n. sp.

1990 Holmia cf. mobergi Bergström - Vidal \& Nystuen (listed in the text).

1990 Holmia cf. mobergi Bergström - Mens et al. (correlation scheme).

1991 Holmia cf. mobergi Bergström - Moczydłowska (mentioned in the text).

1991 Holmia inusitata Ahlberg \& Bergström Moczydłowska (mentioned in the text)

1995 Holmia inusitata Ahlberg \& Bergström - Fritz (mentioned in the text).

1997 Holmia cf. mobergi Bergström - Jensen (listed in the text).

1999 Baltobergstroemia inusitata (Ahlberg \& Bergström) - Liebermann (discussion).

1999 Schmidtiellus sp. - Liebermann (discussion).

2001 Holmia cf. mobergi Bergström - Moczydłowska et al. (compared with $H$. sp.).

2002 Holmia cf. mobergi Bergström - Moczydłowska (mentioned in the text).

2003 Holmia inusitata Ahlberg \& Bergström - Ebbestad et al. (description and figures).

2003 Holmia cf. mobergi Bergström - Ebbestad et al. (discussion and line drawing in table with biozones).

2007 Holmia cf. mobergi Bergström - Nielsen \& Schovsbo (mentioned in the text).

2007 Holmia inusitata Ahlberg \& Bergström - Nielsen \& Schovsbo (mentioned in the text).

2011 Holmia cf. mobergi Bergström - Nielsen \& Schovsbo (mentioned in the text).

2011 Holmia inusitata Ahlberg \& Bergström - Nielsen \& Schovsbo (mentioned in the text).

Holotype: By original designation of Ahlberg \& Bergström, in Ahlberg et al., 1986, pp. 43-45, fig. 3A and refigured by Ebbestad et al. (2003). pl. 1, fig. 1. A partially preserved cephalon with three fragmentary thoracic segments (PMO 113.233) collected by S. Skjeseth from autochthonous strata in the Lauselva river section west of Lake Mjøsa in the early 1950s.

Diagnosis: Emended. A species of Holmia with a perfectly semi-circular cephalic outline and a broad and convex cephalic border with a well-defined border furrow. The glabella is half as long as total cephalic width and subparallel in outline. S3 is transglabellar and undulating. The occipital spine is stout and broad based, medially placed on the occipital ring (LO) while the intergenal spines are small and node-like, placed in line with or slightly outside the ocular lobes (exsag.). Posterior end of ocular lobes is adjacent to the anterior part of LO. Thorax with 19 segments. 
Remarks: Holmia cf. mobergi described from Flagstadelva is here considered conspecific with Holmia inusitata. Holmia sp., sensu Moczydłowska et al. (2001), although very similar to $H$. inusitata, is in need of a more thorough revision and is still left under open nomenclature.
The only known specimen from the Flagstadelva river section, originally determined Holmia cf. mickwitzi, has previously been figured and described as $H$. cf. mobergi in Ahlberg et al. (1986). Liebermann (1999) discussed its affinities and transferred the species to Schmidtiellus
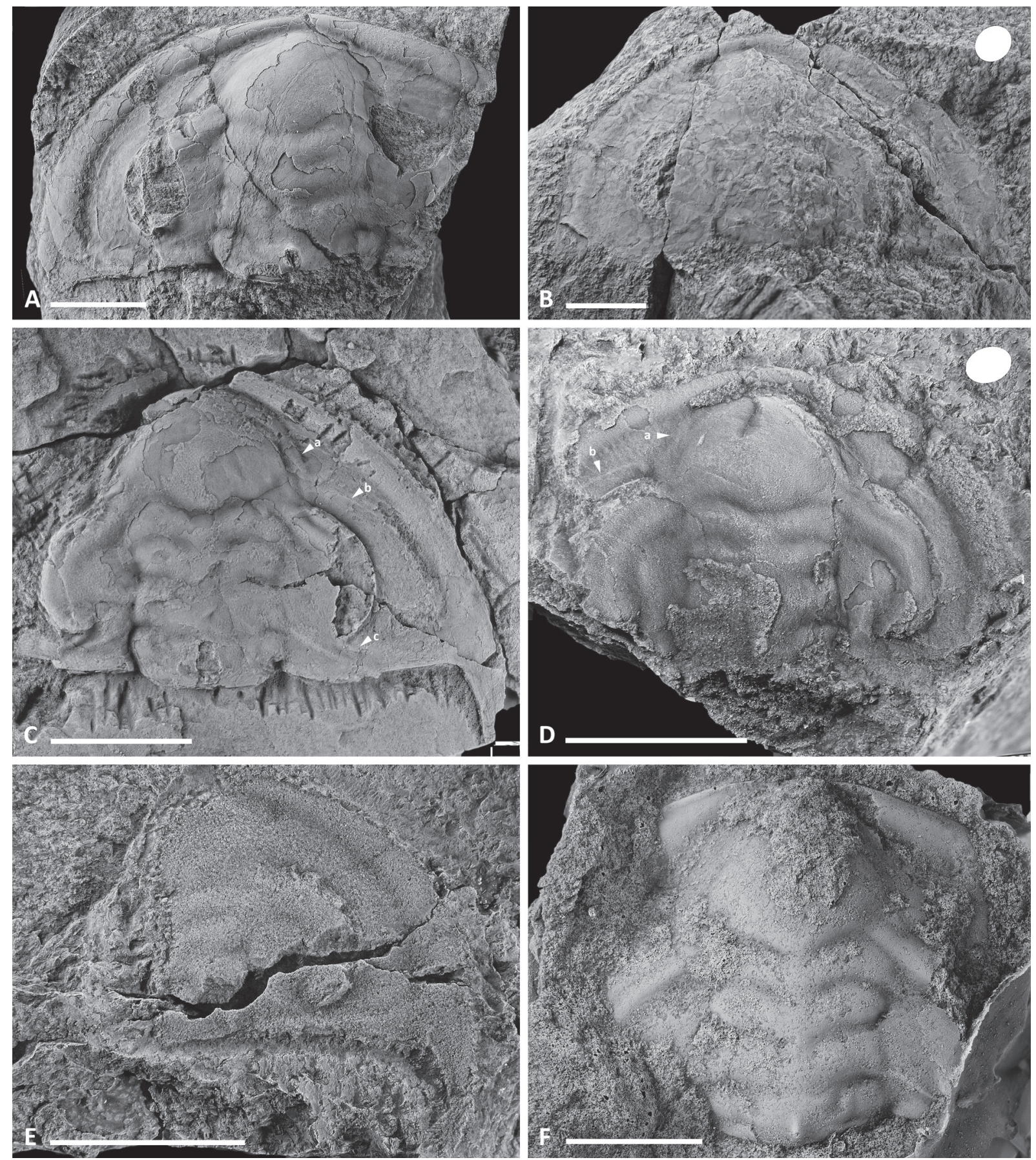

Figure 9. (A) Holmia inusitata (PMO 113.233), coll. S. Skjeseth, early 1950s. A diagonal crack and slight clockwise rotation of the cheek region make the occipital lobe appear wider. Note prominent border. Presumably from $12.5 \mathrm{~m}$ level, Flagstadelva. (B) Holmia inusitata. Retrodeformed large cephalon (PMO 234.271) with strain ellipse showing densely placed compaction cracks, Flagstadelva. (C) Holmia inusitata, cephalon (PMO 234.292) with well-preserved posterior margin. $a$ - parafrontal band, $b$ - anterior metaparian suture, $c$ - posterior metaparian suture. Lauselva, $2 \mathrm{~m}$ level. (D) Holmia inusitata. Retrodeformed, small holaspid cephalon (PMO 234.272/1) with strain ellipse, Flagstadelva. $a$ - parafrontal band, $b$ - anterior metaparian suture. See Fig. 19A for the specimen prior to retrodeformation. (E) Holmia inusitata, partial cephalon (PMO 234.274), Flagstadelva. All Flagstadelva specimens from the $12.5 \mathrm{~m}$ level. (F) Holmia mobergi, holotype (LO 4457T), coll. J.C. Moberg, 1904. Schmidtiellus mickwitzi Zone, Norretorp Formation, Scania, Sweden (original of Bergström, 1973, fig. 3A). Scale bar on $A-C, E \& F=10 \mathrm{~mm}, D=5 \mathrm{~mm}$. Note that scale bars in the retrodeformed specimen are prior to retrodeformation. 
Moberg in accordance with Martinsson (1974). Ebbestad et al. (2003) described and discussed Holmia inusitata, figured all available specimens at that time and sorted out the character variations and distribution within Scandinavian species of Holmia. Similarities between Holmia inusitata and $\mathrm{H}$. cf. mobergi were emphasised in their re-description of $H$. inusitata and both taxa were maintained as distinct species of Holmia.

\section{Description}

\section{Measurements}

The material from both the Flagstadelva and the Lauselva sections shows variable degrees of dorsoventral compaction and/or tectonic deformation, which introduces problems interpreting the original shape of such specimens (Webster \& Hughes, 1999). Length and width measurements on the cephala of these specimens are therefore uncertain and are here only used as a general guide to highlight certain features of the morphology or individual specimens and better understand the deformation involved.

Generally, specimens from the autochthonous Lauselva section are less compacted and show little tectonic deformation, while specimens from the parautochthonous Flagstadelva section are more dorso-ventrally compacted and usually tectonically deformed. Some of the small meraspid specimens from Flagstadelva show less compaction-related deformation while the two large and fairly complete cephala from Flagstadelva (Fig. 9A, B) are rather heavily dorso-ventrally compressed. Similarsized specimens from Lauselva, although dorso-ventrally compacted, typically retain much of the convexity of the glabellar area and palpebral lobes (tr., exsag.) whereas the extraocular area is splayed to various degrees.

Tectonically deformed specimens had to be retrodeformed prior to measurements, which was done based on assumptions at right-angles on the cephalon and comparison of relative proportions from specimens less affected by tectonic deformation (see Żylińska et al., 2013). The elongation of the strain ellipse is $125-135 \%$.

Fifteen specimens from Flagstadelva and ten specimens from Lauselva were suitable for measurements. The morphological variation was captured with a set of 17 linear measurements (Fig. 8A, Table 1) that were subjected to both bivariate and principal component analyses (PCA). Because of missing data, W3, W4 and W8 were omitted in the PCA analysis, leaving 14 measurements and 16 specimens. Although incompletely preserved, measurements of $H$. mobergi Bergström from Scania, southern Sweden (Fig. 9F), are included in Table 1 and some of the bivariate plots.
Glabellar length could be measured in fourteen specimens from Flagstadelva, and eleven of these are smaller than the smallest specimen from Lauselva. The average glabellar length of presumed meraspid specimens from Flagstadelva (glabellar length shorter than $8.0 \mathrm{~mm}$ ) is $4.18 \mathrm{~mm}(\mathrm{n}=5)$, while the average glabellar length for presumed holaspid specimens from Flagstadelva is $17.33 \mathrm{~mm}(\mathrm{n}=9)$. Specimens from Lauselva have an average glabellar length of $25.11 \mathrm{~mm}(\mathrm{n}=10)$. The standard deviation of the glabellar length measurements of the Flagstadelva specimens is greater than that of the Lauselva specimens (9.57 vs. 3.79 ) showing that the latter sample is much more homogeneous in its size distribution. The Flagstadelva sample has more specimens in the lower size classes (glabellar length less than $5 \mathrm{~mm}$ ) and fewer of the large specimens (glabellar length greater than $12 \mathrm{~mm}$ ). The greatest glabellar length measured on a Flagstadelva specimen is greater than any of the measurements on the Lauselva specimens (Table $1)$.

Bivariate plots of linear measurements yield for the most part a fairly close relationship between the Flagstadelva and Lauselva specimens, but with some exceptions. Sagittal glabellar length (GL) plotted against the width (tr.) at the occipital lobe (W5) places the Lauselva specimens a bit lower on the y-axis, meaning that the glabellar length is proportionally longer relative to W5 in this sample set (Fig. 8B); a Student's t-test shows that there are no significant differences in the slopes between the regression lines in the two samples. The original $H$. cf. mobergi specimen (Fig. 9A) has the widest posterior width relative to glabellar length of the Flagstadelva specimens, followed by the third largest specimen (Fig. 9B). Both of these show a substantial degree of dorso-ventral flattening. Specimen in Fig. 9C is a fairly representative specimen from Lauselva with regard to these measurements, while specimen in Fig. 10B has a proportionally narrow posterior width and specimen in Fig. 13B is closer to the larger Flagstadelva specimens. In the largest specimen from Flagstadelva (Fig. 10A, B) the anterior margin of the glabella is a bit deformed, which may have affected the length measurement. Otherwise, the original convexity of the specimen in Fig. 10B, D \& F is well-preserved.

One of the most variable linear interrelationships is between the width across the palpebral lobes (W7) and the width of the extraocular area (W10) (Fig. 8C). Generally, specimens from Lauselva have a greater width of the extraocular area than the Flagstadelva specimens. See Figs. 11A, B, C, \& 13A, B, C, D and also PMO 169.669/1 in Ebbestad et al., 2003, plate 1, fig. 2. Exceptions are specimens shown in Fig. 9C and 10B, which correspond well with specimens from Flagstadelva (compare Fig. 9A \& 9C). The differences are most likely due to the different compressional settings of the specimens as discussed above and partly size-related as discussed under ontogeny. 


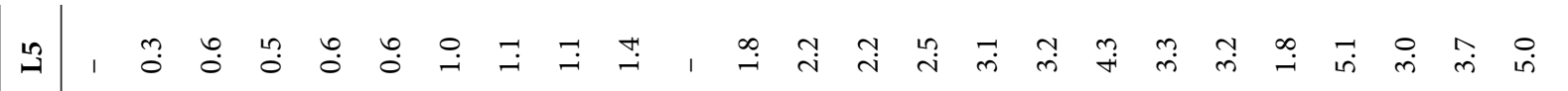

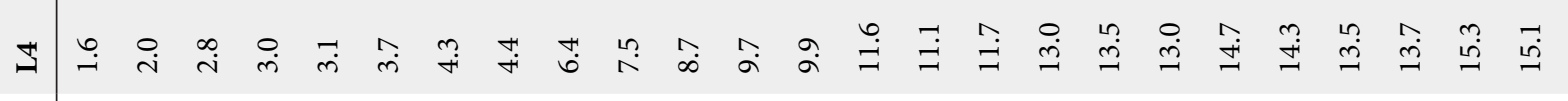

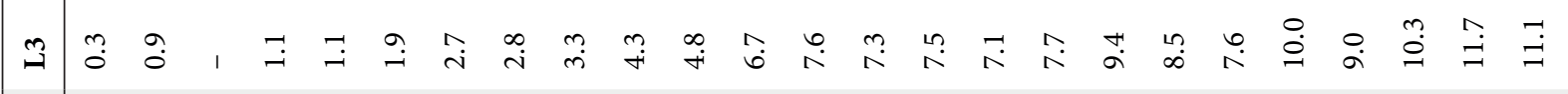

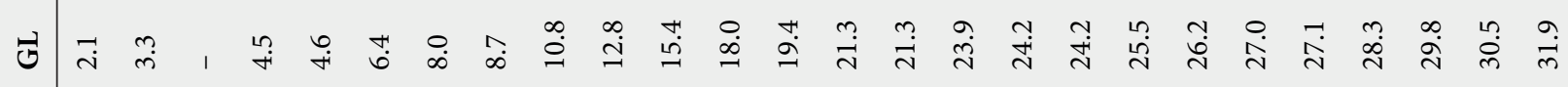

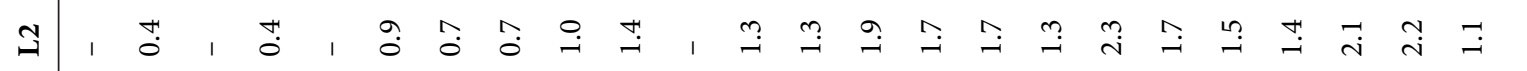

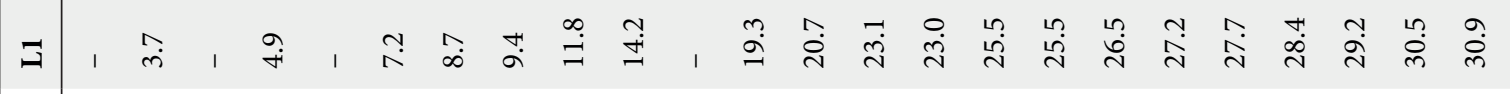

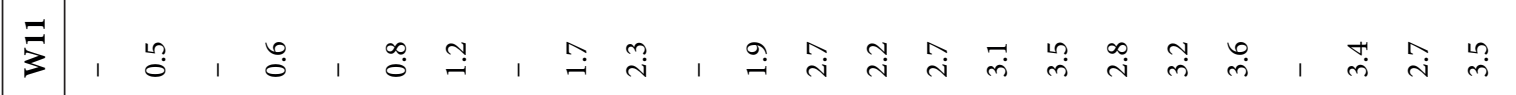

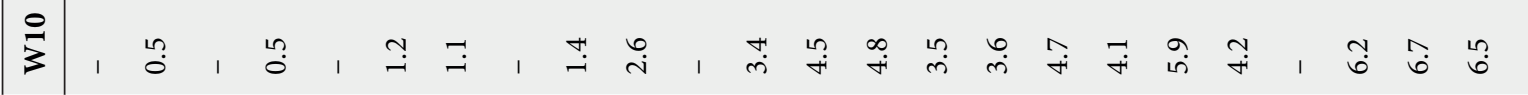

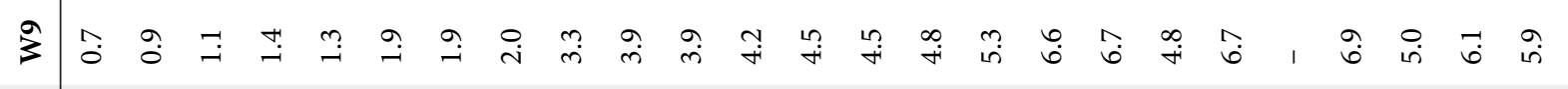

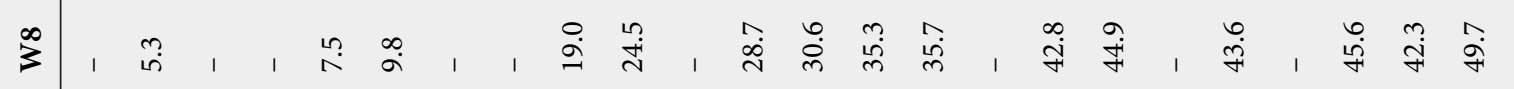

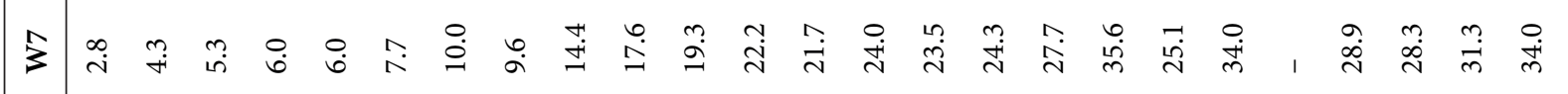

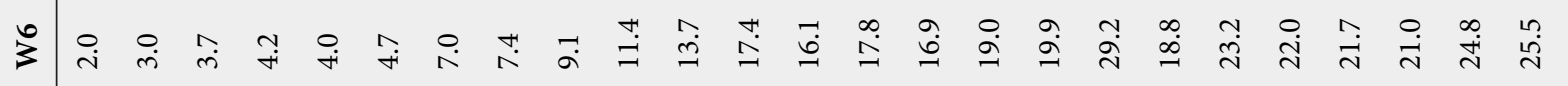

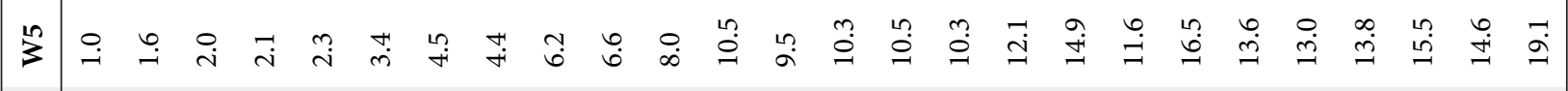

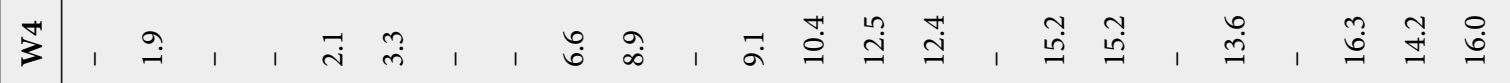

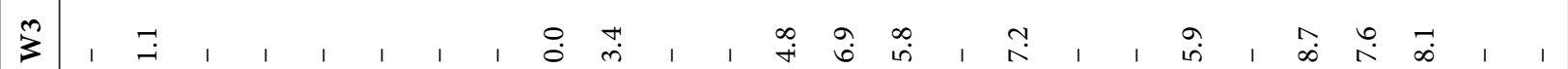

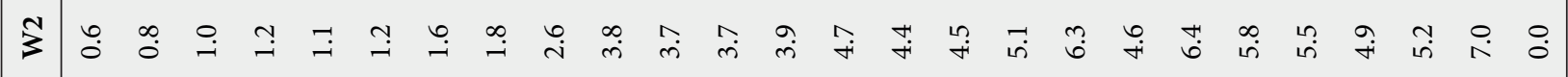

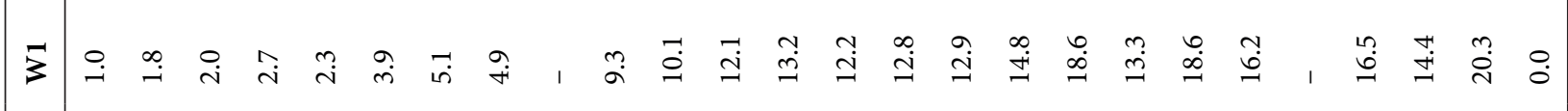

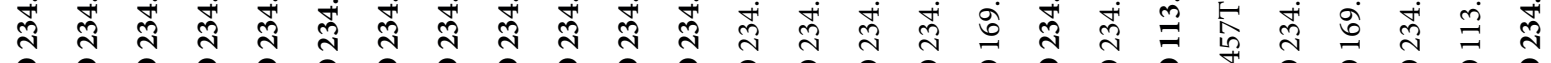
$\sum_{i=1}^{0} \sum_{i=1}^{0} \sum_{i=1}^{0} \sum_{i=1}^{0} \sum_{i=1}^{0} \sum_{i=1}^{0} \sum_{i=1}^{0} \sum_{i=1}^{0} \sum_{i=1}^{0} \sum_{i=1}^{0} \sum_{i=1}^{0} \sum_{i=1}^{0} \sum_{i=1}^{0} \sum_{i=1}^{0} \sum_{i=1}^{0}$

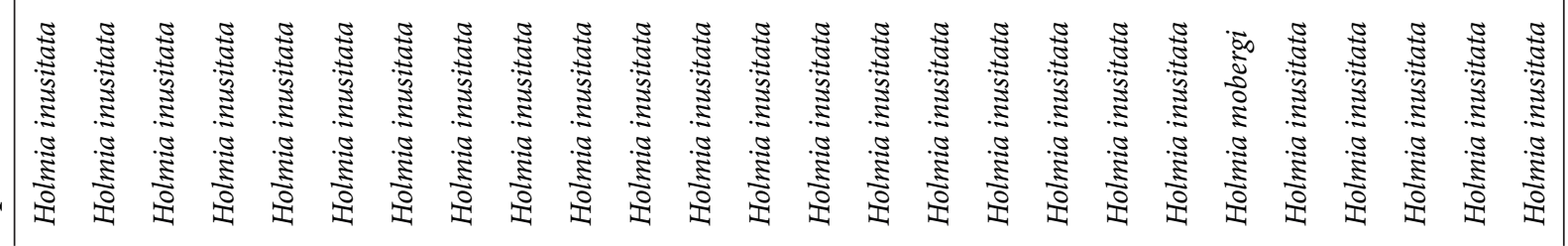


Two specimens have a markedly longer postocular length (L5) (exsag.) relative to the glabellar length than in other Flagstadelva and Lauselva specimens (Fig. 8D). Holmia mobergi Bergström (Fig. 9F) is included for comparison, demonstrating a very short L5 relative to the glabellar length. The long L5 is found in the specimen in Fig. 9B from Flagstadelva and the holotype of $H$. inusitata (see Ebbestad et al., 2003, plate 1, fig. 1) from Lauselva. In general, L5 tend to be marginally longer in larger specimens (glabellar length $>19 \mathrm{~mm}$ ), which may relate to ontogeny. However, both the mentioned specimens are tectonically deformed, which likely explains the anomaly in the L5 data.

The first principal component (PC1) in the Principal Component Analysis (PCA) relates to increase in the size of the specimens, becoming larger towards the right on PC1 (Fig. 8E). The second principal component (PC2) reflects a number of morphological variations and ontogeny. Especially the width measurements (W1, W5W7) have large positive loadings on PC2, while lengths (L1, GL, L4) and the width of the extraocular area (W10) have large negative loadings on PC2 (Table 2).

There is a clear relationship between the glabellar length and the width across the palpebral lobes (W7) for the large specimens from Lauselva (right side of PC1). Specimens with a low score on PC2 have a subequal length/width relationship, whereas W7 progressively becomes proportionally greater higher on PC2. The posterior width of the glabella (W5) is about $50 \%$ of the

Table 2. PCA loadings for the first three principal components.

\begin{tabular}{llll}
\hline & PC1 & PC2 & PC3 \\
\hline W1 & 0.25562 & $\mathbf{0 . 3 4 5 3}$ & 0.63802 \\
W2 & 0.083999 & 0.15114 & 0.11141 \\
W5 & 0.23088 & $\mathbf{0 . 2 4 7 1}$ & -0.29897 \\
W6 & 0.36081 & 0.11894 & -0.52687 \\
W7 & 0.46433 & $\mathbf{0 . 5 0 0 1 6}$ & -0.064043 \\
W9 & 0.090187 & $\mathbf{0 . 2 0 4 1 6}$ & 0.051696 \\
W10 & 0.099211 & $\mathbf{- 0 . 2 5 4 8 2}$ & 0.039365 \\
W11 & 0.051572 & 0.043252 & 0.064938 \\
L1 & 0.47296 & -0.42561 & 0.27689 \\
L2 & 0.020874 & -0.027837 & 0.22049 \\
GL & 0.45209 & $\mathbf{- 0 . 3 9 7 7 8}$ & 0.056406 \\
L3 & 0.16143 & $\mathbf{- 0 . 2 8 4 7 5}$ & -0.26206 \\
L4 & 0.22373 & 0.0095245 & -0.061411 \\
L5 & 0.056849 & -0.052525 & -0.0091946 \\
\hline
\end{tabular}

glabellar length, which is average, and the specimens with the lowest score tend to have a bit longer palpebral lobes (L4) relative to W7. The original $H$. cf. mobergi (Fig. 9A) plots high on PC2 owing to a combination of a wide W7, a proportionally wide $\mathrm{W} 5$ and short L4 relative to W7.

Meraspid specimens with a glabellar length shorter than $10 \mathrm{~mm}$ are clustered quite closely on the left side of PC1 and have low negative scores on PC2. They do not have the same W7-GL relationship as the large specimens. Instead, the meraspids have long, narrow glabellas with a short frontal lobe (L3), wide W7, and long L4 relative to glabellar length (Figs 9D, 17B, D \& 18). Two early holaspid specimens a bit higher on PC2, Figs. 9E \& 19C, $\mathrm{D}$, also have long L4 but proportionally much wider W7 than the smaller specimens. A slightly larger and flattened specimen, PMO 234.276 (not figured), compare well with the larger Lauselva specimens. The W7 is slightly larger and the W5 value is high, placing it higher on PC2.

The bivariate and PCA analyses highlight some general aspects of this material. The parameters that most strongly influence variations are the glabellar length, palpebral lobe length, length of the frontal glabellar lobe, width across the palpebral lobes and posterior width of the glabella. Especially the width measurements seem susceptible to compaction-related deformation, but differently among the specimens; small meraspids are largely unaffected, larger specimens from Flagstadelva are flattened, while Lauselva specimens retain convexity but with the extraocular area typically splayed and reflected in larger values for W10. The meraspids stand out with narrow glabellas and long palpebral lobes, changing through the ontogeny to shorter L4 and broader W7. Larger specimens from Flagstadelva typically have wider W7 and W5 relative to GL than the Lauselva specimens, most likely reflecting different degrees of compressional compaction.

\section{Cephalon}

Ebbestad et al. (2003) erroneously suggested that the cephalic outline in $H$. inusitata was slightly pointed, which was based on the only known cephalon at that time with the outer margin partly preserved. A pointed cephalic outline is commonly observed in other Baltoscandian olenellids and is here interpreted as a preservational condition. It was also stated, based on the holotype, that L1 is extended postero-laterally onto the palpebral area (Ahlberg et al., 1986, p. 43; Ebbestad et al., 2003, p. 1046), but this is caused by wrinkling of the interocular area. L1 is distinctly outlined laterally by an axial furrow in line with the other glabellar lobes (Figs. 9A, C, 10B, 11C \& 13A, B). Furthermore, the cephalic length/width ratio is close to 0.5 ; the glabellar length being half the cephalic width and not less than two-thirds of the maximum cephalic width as previously stated. 

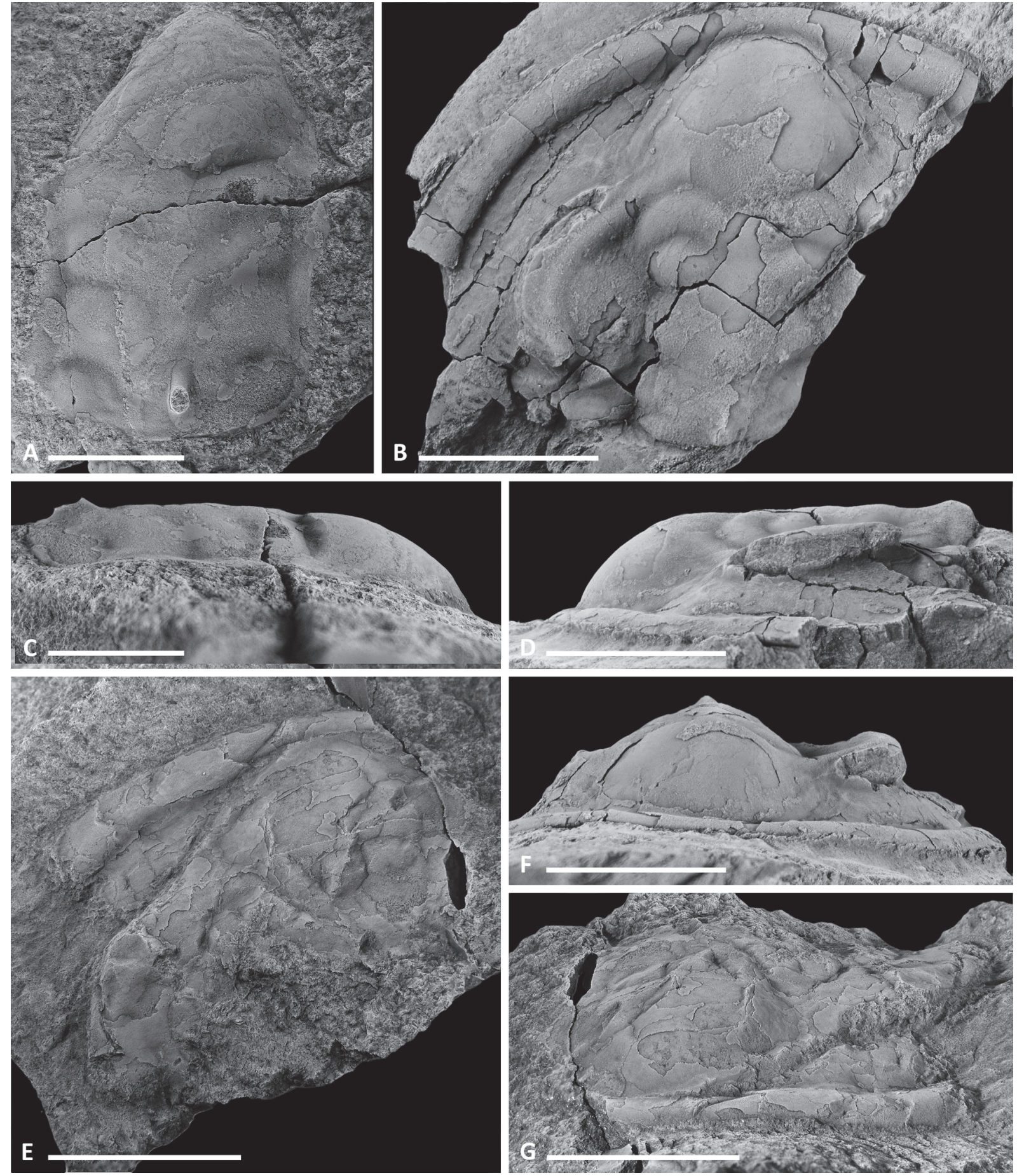

Figure 10. Holmia inusitata. (A \& C) Largest glabella collected (PMO 234.268/3), dorsal and lateral view. Note position of base of prominent occipital spine. Flagstadelva. (B, D \& F) Partial cephalon (PMO 234.293) in dorsal, lateral and anterior view, transversally slightly compressed. Note prominent anterior border. Lauselva, 1.5-2.0 m level. (E \& G) Large fragmentary and tectonically compacted cephalon (PMO 234.277). Note prominent anterior border. Dorsal and anterior view. Flagstadelva. Flagstadelva specimens collected at $12.5 \mathrm{~m}$ level. All scale bars $=10 \mathrm{~mm}$.

Striking characteristics of the Flagstadelva specimens are the prominent and convex cephalic border in front of the glabella that gradually widens laterally. The border furrow is distinct and clearly separates the anterior glabellar lobe from the anterior border.

The extraocular area is wider than the antero-lateral border. These features are in common with $H$. inusitata from the type locality at Lauselva and to some degree $H$. mobergi from the Schmidtiellus mickwitzi Zone, Scania, southern Sweden, H. sulcata Bergström, 1973 from the H. kjerulfi Group Zone, Scania, southern Sweden, Holmia sp. sensu Moczydłowska (2001) from the S. mickwitzi Zone, Storuman area in southern Swedish Lapland, and to some extent $H$. grandis Kiær, 1917 from the H. kjerulfi Zone, Mjøsa area. No other Scandinavian holmiids show these features. 
The stout spine, medially positioned on the occipital lobe in the Flagstadelva material (Fig. 9A, 10A) corresponds well with $H$. inusitata and $H$. sp. The preserved occipital spine on the counterpart (PMO 234.268/3B, not figured) of the specimen in Fig. 10A is $7.5 \mathrm{~mm}$ long. A stout spine is a character not found in $H$. mobergi or $H$. sulcata. In $H$. mobergi, the spine is tiny and positioned closer to the posterior margin (Fig. 9F) and the species is further separated from $H$. inusitata by the longer ocular lobes with the distal ends adjacent to midway on the occipital lobe and S3 is not transglabellar. H. grandis is distinguished from all other Holmia species by the comparatively short ocular lobes, narrower anterolateral border and wider extraocular area. A well-developed transglabellar S3 is seen in the Flagstadelva material, in $H$. inusitata from Lauselva and seemingly present in the few figured specimens of $H$. sp. from Storuman.
Slight compaction of the cephalon usually exaggerates the glabellar furrows and gives them a transglabellar appearance (Fig. 19E).

The Flagstadelva material has a proportionally less expanded frontal lobe, compared to the stratigraphically younger $H$. kjerulfi, $H$. lapponica Ahlberg \& Bergström and $H$. cf. lapponica. This lobe is slightly wider than LO, while L1 and L2 are slightly narrower than LO, giving the glabella a subparallel appearance. The same conditions are seen in $H$. inusitata, $H$. sp., H. mobergi and in species of Schmidtiellus, the stratigraphically oldest Baltoscandian olenellid taxa. The new topotype material of $H$. inusitata possesses long and straight posteriorly directed genal spines, extending back to the tenth thoracic segment (Fig. 13A, C). The cephalon is covered with a reticulate pattern in well-preserved specimens.
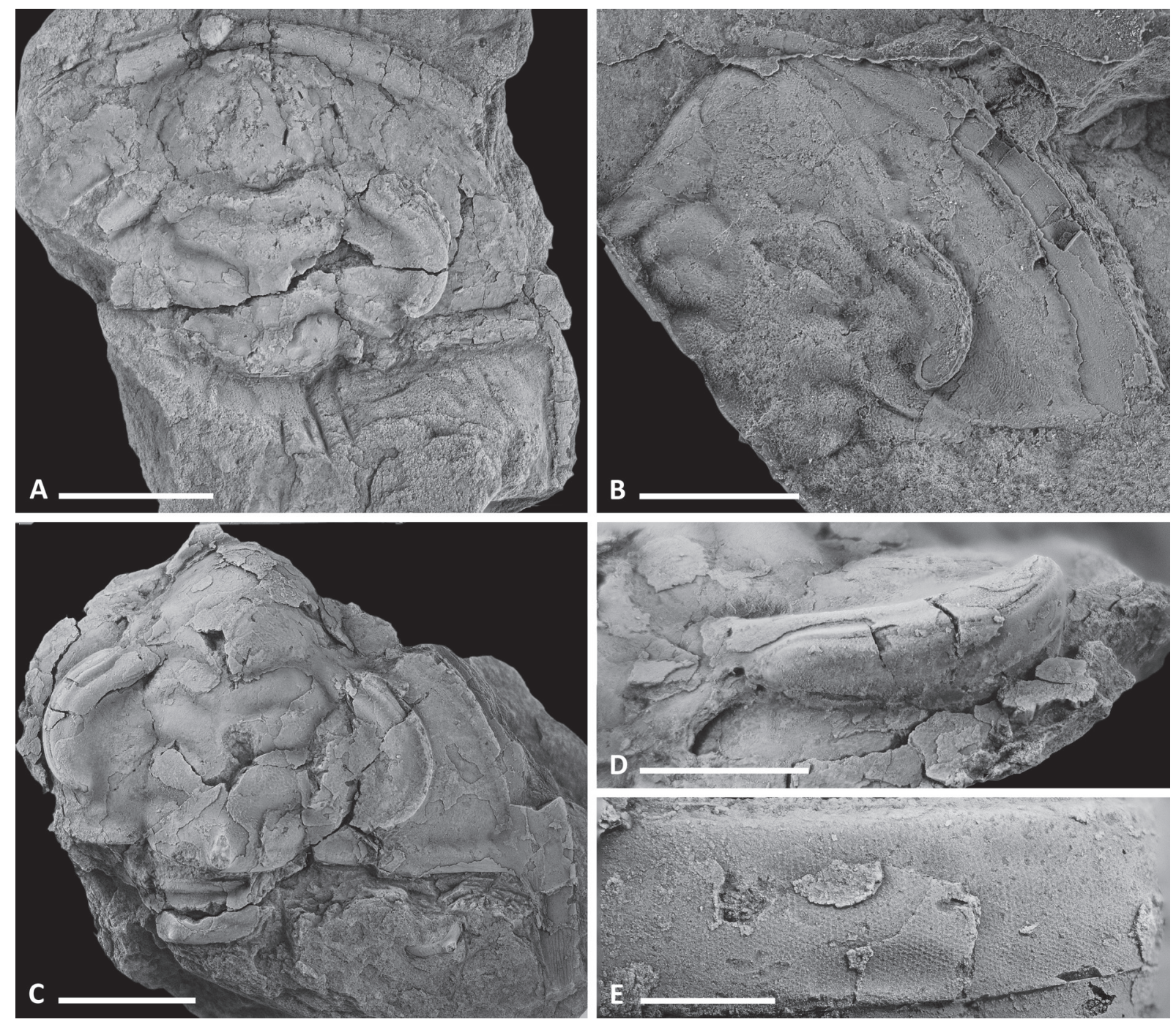

Figure 11. Holmia inusitata. (A) Flattened cephalon (PMO 234.294), making the extraocular area appear wide. (B) Silicone cast of cephalon (PMO 234.295) displaying well-preserved reticulate pattern. (C) Partial cephalon (PMO 169.670) showing exceptionally preserved compound eye consisting of thousands of facets (original of Ebbestad et al. 2003, plate 1, figs. 3,4,6 \& 8 and plate 2, Fig. 15). (D \& E) Close-ups of specimen in C. Lateral views of compound eye. All specimens collected between 1.5-2.0 m level, Lauselva. Scale bars on $A-C=10 \mathrm{~mm}, D=5$ $m m, E=1 \mathrm{~mm}$. 
A parafrontal band is seen in both the Lauselva and the Flagstadelva material (Fig. 9C, D). Its functional morphology is discussed under the description of the hypostome.

Størmer (1942) drew attention to a pair of faintly raised lines in the cheek region of $H$. kjerulfi and Kjerulfia lata. These lines were termed the anterior and posterior eye lines. Harrington (in Moore, 1959, figs. 45J and 48B) interpreted the lines as a fused facial suture and named it a metaparian suture; a non-functional suture in a state of complete symphysis. Whittington (1997) doubted this interpretation. Faintly raised metaparian suture-lines are seen in $H$. inusitata from Lauselva and Flagstadelva (Fig. 9C, D).

One specimen collected from Lauselva (Fig. 11C-E) shows an extraordinarily well-preserved, compound eye. This is among the oldest known visual surfaces in the fossil record of densely packed lenses and shows that $H$. inusitata already had established compound eyes consisting of thousands of hexagonally arranged facets, each with a diameter of $\sim 0.03 \mathrm{~mm}$. Similar structures of the visual surface are also found in $H$. kjerulfi. Schmidtiellus reetae Bergström, a stratigraphically older trilobite known from the Schmidtiellus Zone in Estonia, displays relatively larger lenses counting less than one hundred on each visual surface (Schoenemann et al., 2017).

\section{Hypostome}

A hypostome conjoined with the rostral plate is preserved in situ in a nearly complete specimen prepared from the ventral side and collected in the Lauselva section (Figs. 12B \& 13C). The hypostome is slightly wider than long, and the anterior wings are joined to the ventral side of the cephalon corresponding to where the parafrontal bands are situated dorsally on each side of the glabellar frontal lobe. The furrow between the parafrontal band and the anterior lobe may indicate an apodemal pit corresponding to a ventral process for attachment of ligaments in connection with the hypostome (Figs. 12D \& 13C). Whittington (1987, text-fig. 3) questioned a suture separating this sternite
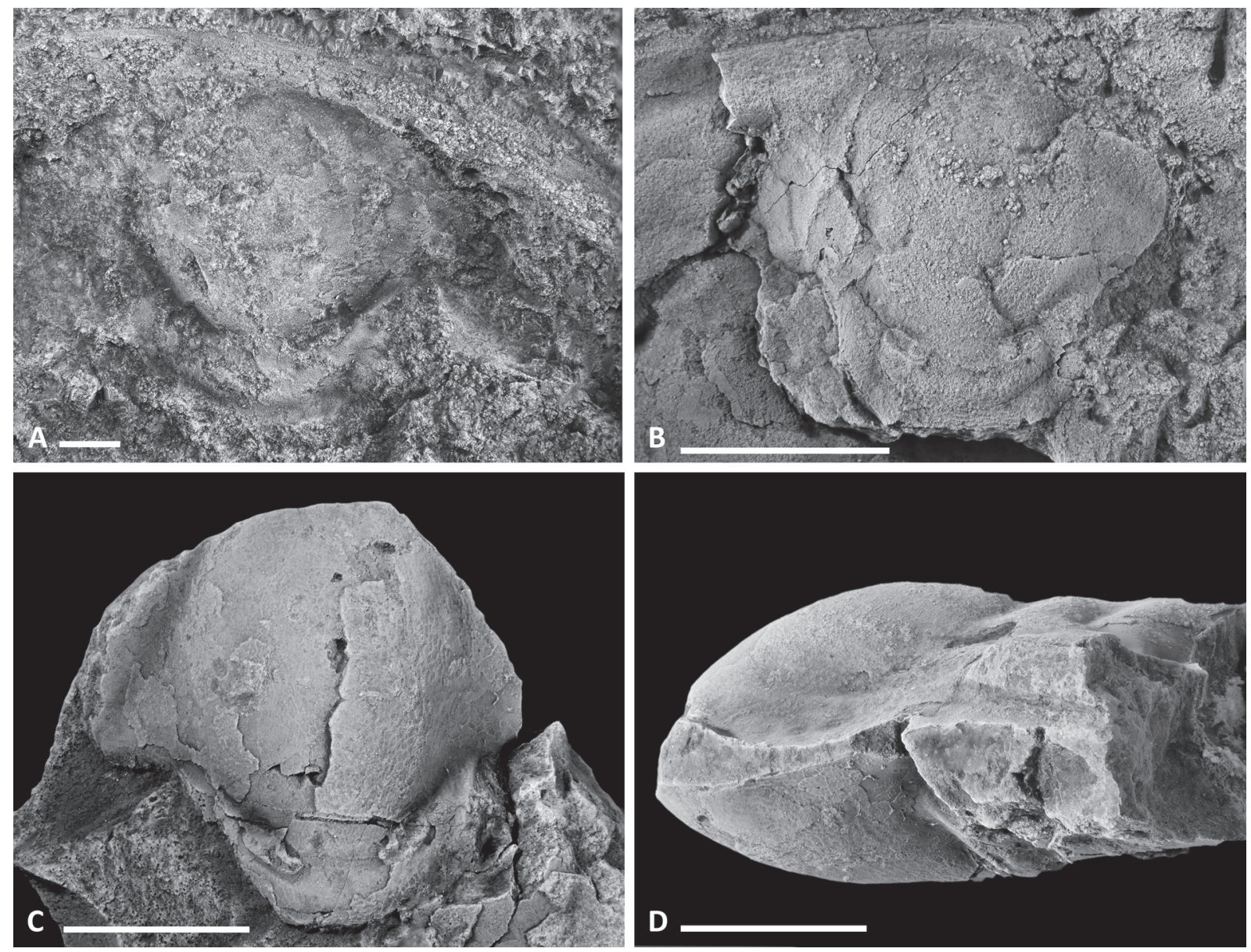

Figure 12. Hypostomes of Holmia inusitata. (A) Poorly preserved and tectonically slightly skewed hypostome and rostral plate (PMO 234.279). Flagstadelva, $12.5 \mathrm{~m}$ level. (B) Well-preserved and in situ on nearly complete specimen (PMO 234.290), same as in Fig. 13C. Lauselva. (C \& D) Ventral and lateral view of articulated hypostome and glabella (PMO 234.296). Note hypostomal anterior wing below the parafrontal band and pit. Lauselva. Lauselva specimens collected from 1.5-2.0 $\mathrm{m}$ level. Scale bars on $A=1 \mathrm{~mm}, B-D=5 \mathrm{~mm}$. 

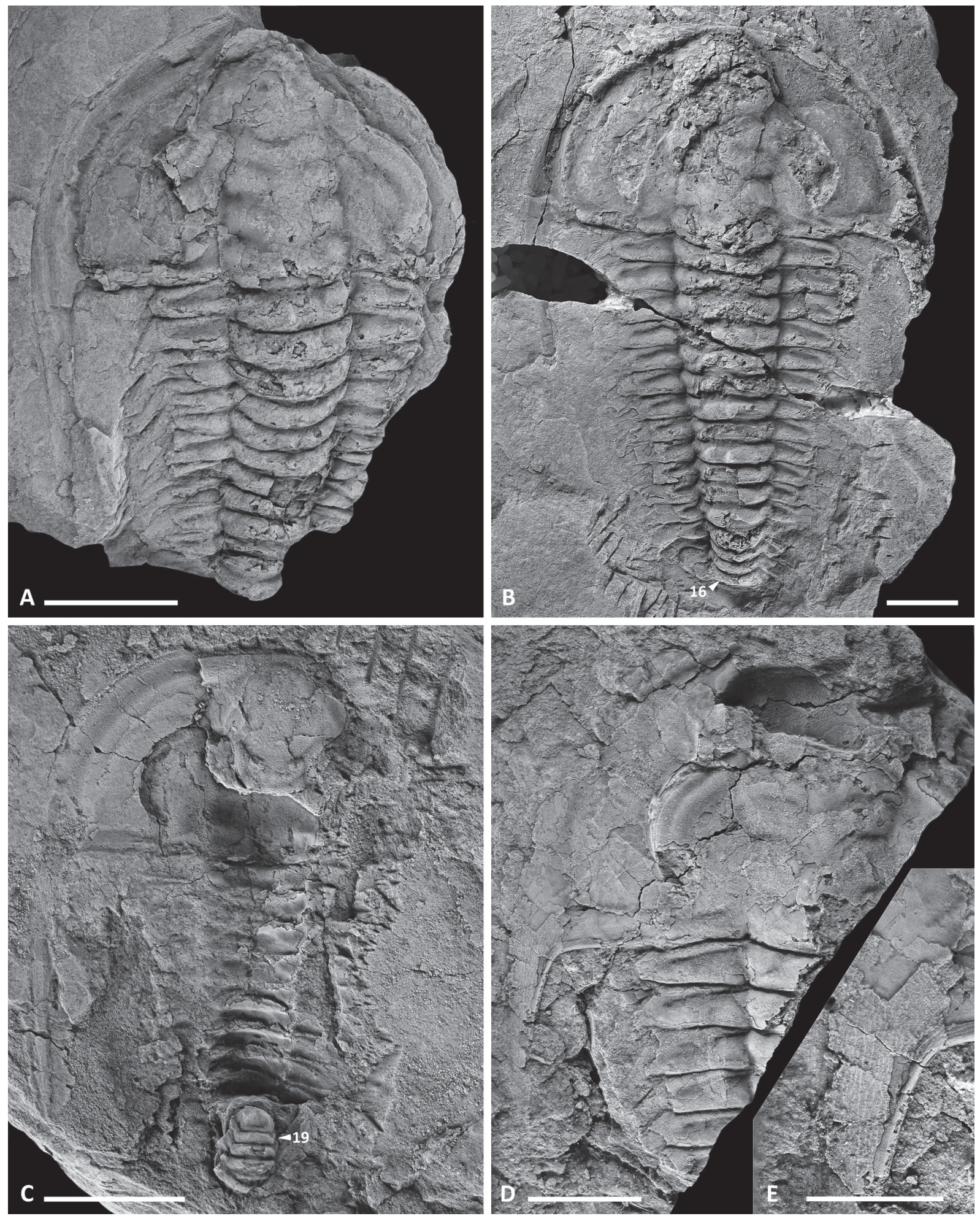

Figure 13. Holmia inusitata. (A) Cephalon with 11 articulated thoracic segments (PMO 234.288). Note very long genal spine. (B) Largest specimen (PMO 234.289), nearly complete, showing 16 articulated thoracic segments (16 ${ }^{\text {th }}$ segment labelled. See Fig. 14A for detail). (C) Nearly complete specimen (PMO 234.290), ventral side with hypostome in situ and thorax curled posteriorly, showing pygidium (19 ${ }^{\text {th }}$ segment labelled. See Fig. 14B for detail). Note very long genal spine exceeding the $11^{\text {th }}$ thoracic segment. (D) Large partial specimen (PMO 234.291) with wellpreserved cephalic posterior margin, inner genal spine angle and pleural fields. Hypostome slightly displaced beneath anterior glabellar lobe. (E) Close-up of D showing raised terrace lines on the genal spine. All specimens collected at Lauselva from 1.5-2.0 m level. Scale bars on A-D $=10 \mathrm{~mm}, E=5 \mathrm{~mm}$.

from the rostral plate in $H$. kjerulfi, based on reported collections of isolated hypostomes of the species. In $H$. inusitata, the hypostome is conjoined with the rostral plate in both small and large specimens. The anterior lobe is prominent and almost five times as long (sag.) as the posterior lobe. A pair of maculae is placed adjacent 
to the midway on the lateral border and a pair of short spines are situated on the lateral margin opposite the posterior ends of the maculae. The posterior border is uniform in length (sag.) and a pair of short spines are present postero-laterally on the posterior margin. The posterior margin of the hypostome is on level with the glabellar S1. The hypostomal lobes are covered with a fine ornamentation consisting of an irregular reticulate pattern that is co-marginal on the posterior border. Four hypostomes from the Flagstadelva section agree well with those in the topotype material (Fig. 12). The hypostomes in $H$. inusitata and $H$. kjerulfi are very similar when the reticulate surface sculpture is not preserved. In $H$. cf. lapponica, the posterior lobe appears proportionally longer (sag.) and narrower (tr.) and the hypostome and rostral plate are densely ornamented with irregular terrace lines (Høyberget et al., 2015, fig. 6L). A fragmentary hypostome of $H$. sp. (Moczydłowska et al., 2001, fig. 7f) is similar to $H$. inusitata and the seemingly long lateral border in the figured specimen is due to an exsagittal crack of the anterior lobe near the base of the anterior wings.

\section{Thorax}

The exact number of thoracic segments is unknown, but 14 visible axial rings are counted in Fig. 13C, where probably some 5 segments are hidden beneath the posteriormost, enrolled tergites. Another specimen has 16 segments preserved (Fig. 13B), but judging from the angle between the pleural field and the axial ring in the last preserved segment, no fewer than 3 segments are missing (compare Fig. $14 \mathrm{~A}$ and B). Therefore, $H$. inusitata apparently has 19 thoracic segments (H. kjerulfi and H. lapponica have 16 and 15 segments, respectively). The pleural field is about two-thirds as wide as the axial ring, excluding the pleural spine. The spine is, like in all other Holmia species, constricted at its base and the outline appears thorn-shaped. The pleural spine of $H$. mobergi (Fig. 15F) from Scania, Sweden, has a more convex anterior margin and appears more sickle-shaped. The length of the pleural spine in H. inusitata, measured along the anterior margin, is about equal to the length (sag.) of 2 to 2.5 axial rings. The axial spines gradually increase in size towards the $9^{\text {th }}$ segment (Fig. 15A, E, G \& H), which has an axial macrospine (Fig. 15I). A macrospine is also seen on the $9^{\text {th }}$ segment in PMO 234. 282 from Flagstadelva and PMO 234.305 from Lauselva (not figured herein). In $H$. kjerulfi, the axial spines are gradually increasing backwards, the largest spines being on the $12^{\text {th }}$ and $13^{\text {th }}$ segments. The two posteriormost segments in $H$. kjerulfi and at least the four posteriormost segments in H. inusitata appear spineless (Fig. 14).

A pair of bulges is present antero-laterally on each axial ring (Fig. 15A, C \& E), except in the posteriormost few rings (Fig. 15G), making the axial rings distinctly wider in the anterior half. These bulges are separated by shallow furrows directed adaxially forward. The furrow separating the articulating half-ring is deep and well-developed. The articulating sockets and processes, posteriorly and anteriorly placed along the axial furrow on each segment (Fig. 15J) are well-developed, as known in H. kjerulfi (Whittington, 1990). H. inusitata also shows an angular projection (Fig. 15B) similar to that in $H$. kjerulfi, although the articulating flange along the anterior margin on each pleura known in H. kjerulfi is not obvious in $H$. inusitata. The axis and pleural fields are covered with the same reticulated ornamentation as the cephalon and hypostome (Fig. 15G).

\section{Pygidium}

The pygidium of $H$. inusitata is here figured for the first time (Figs. 13C \& 16A, B, D \& E). The shield is highly vaulted and wider than long, with steep, almost vertically
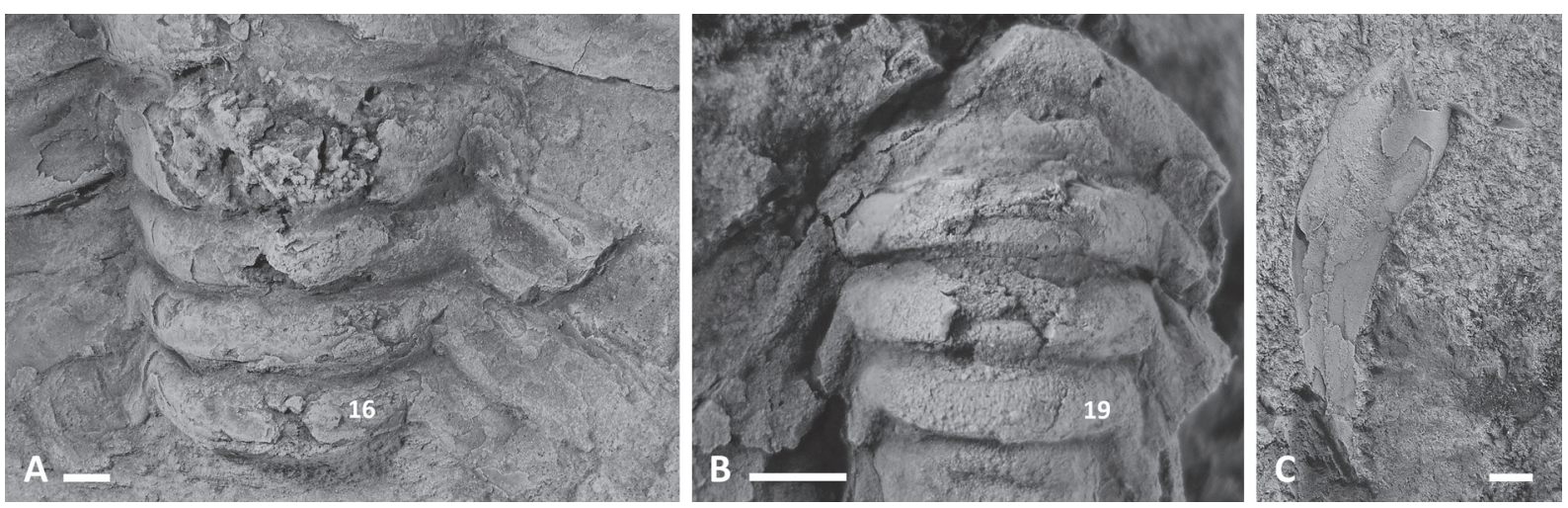

Figure 14. Holmia inusitata. (A) Detail of posteriormost thoracic segments of PMO 234.289 from Lauselva, showing the angle between the axial ring and pleural field in the $16^{\text {th }}$ segment (labelled, see Fig. $13 \mathrm{~B}$ for the entire specimen and corresponding label). (B) Detail of posteriormost thoracic segments of PMO 234.290 from Lauselva showing the angle between the axial ring and the pleural field in the $19^{\text {th }}$ segment (labelled, see Fig. 13C for the entire specimen and corresponding label). (C) Isolated posteriormost thoracic segment from Flagstadelva. Note the nearly 90 degree angle between the fragmentary axial ring and the inner margin of pleural field (PMO 234.286). Scale bars = $1 \mathrm{~mm}$. 

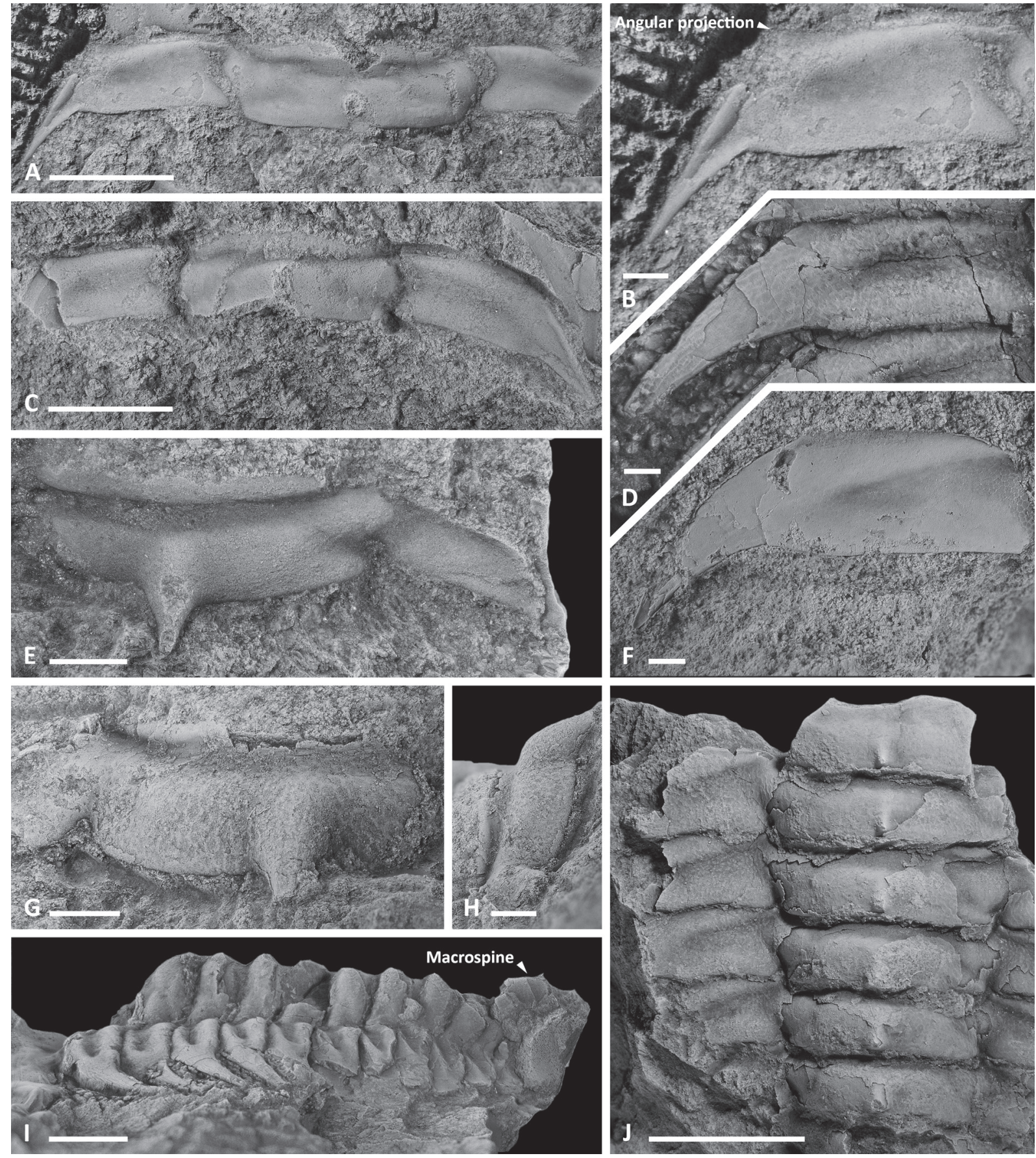

Figure 15. Thoracic segments of Holmia inusitata and H. mobergi. (A) Anterior segment (PMO 234.283) with small spine midway on axial ring. Note thorn-like constriction at the base of the pleural spine. Flagstadelva. (B) Close-up of A, arrow points to angular projection. (C) Midway to posteriorly placed segment (PMO 234.284), Flagstadelva. (D) Third segment on large part of an articulated thorax figured in I. Lauselva. (E) Posteriorly placed segment (PMO 234.285) with prominent axial spine and deep articulating furrow. Flagstadelva. (F) Pleural field of posteriorly placed thoracic segment of $\mathrm{H}$. mobergi (LO 4461T. Original of Bergström, 1973, fig. 6B). Scania, Sweden. (G, H) Dorsal and lateral view of posteriorly placed segment (PMO 234.298) with large axial spine and reticulated test preserved. Lauselva. (I) Paratype specimen (PMO 113.234). Lateral view of eleven anteriormost segments. Note highly vaulted axial rings and macrospine on $9^{\text {th }}$ ring. Collected by S. Skjeseth in the early 1950s, Lauselva. (original of Ahlberg \& Bergström, 1986, fig. 3B and refigured by Ebbestad et al. 2003, plate 2, fig. 10, prior to preparation). (J) Seven articulated segments (PMO 234.297) showing articulating sockets and processes on right side. Lauselva. All Flagstadelva specimens collected at the $12.5 \mathrm{~m}$ level. All Lauselva specimens collected between the 1.5 and $2 \mathrm{~m}$ levels. Scale bars on A, C, I \& J $=5 \mathrm{~mm}, \mathrm{~B}, \mathrm{D}-\mathrm{H}=1 \mathrm{~mm}$.

inclined and narrow pleural fields. No border or spines are seen. One prominent axial ring with a distinct ring furrow is seen anterior to the terminal axial piece, and runs into a pair of faintly indicated pleural ridges (Fig.
16A). The median posterior margin of the terminal axial piece has a small indentation. Pygidia are hitherto only known from three species of Holmia, all being micropygous. The pygidia of $H$. inusitata and $H$. kjerulfi 

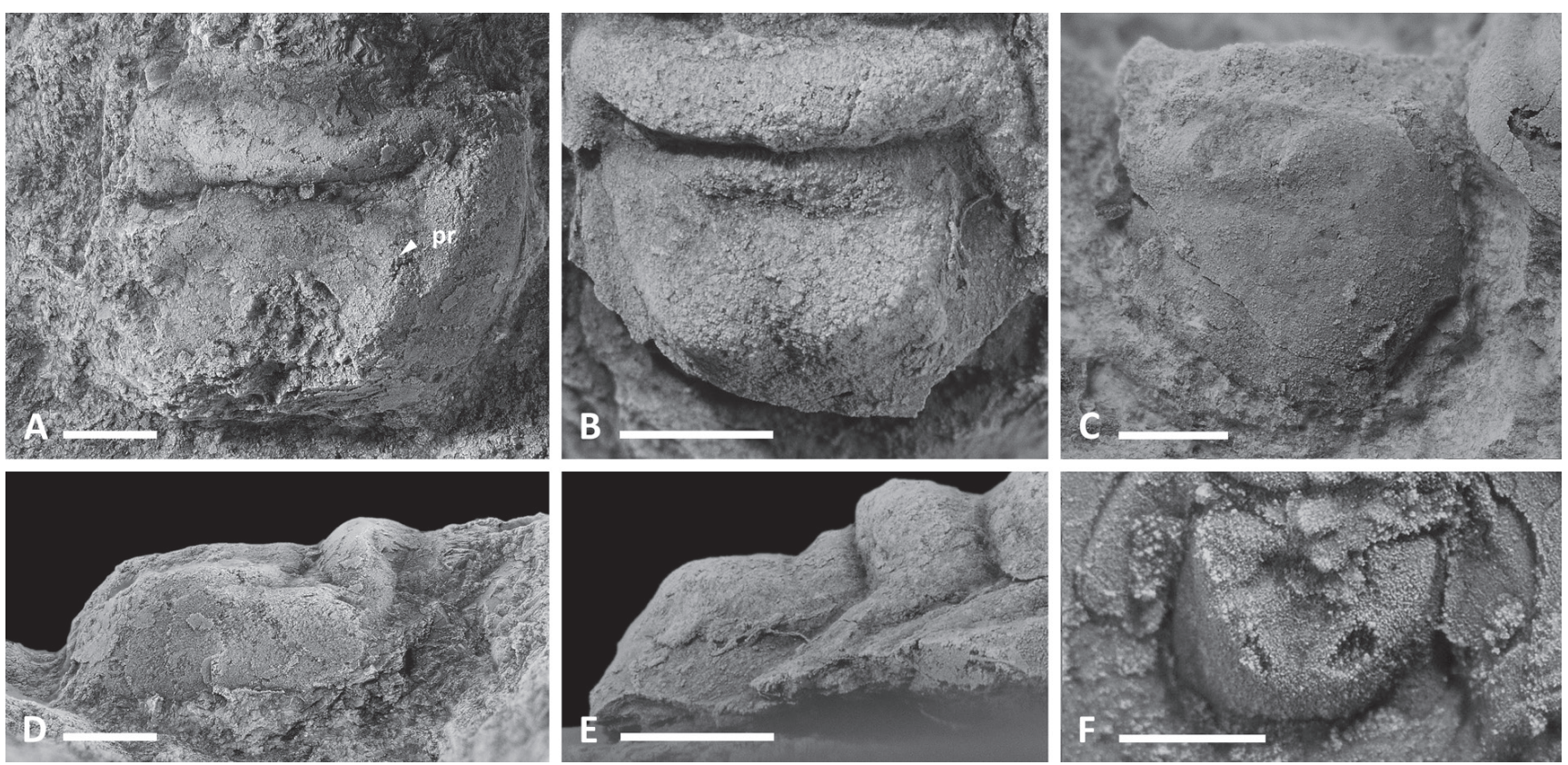

Figure 16. $(A \& D)$ Dorsal and lateral view of partially preserved pygidium of Holmia inusitata (PMO 234.287), arrow points to faintly raised pleural ridge (pr). Flagstadelva, $12.5 \mathrm{~m}$ level. $(B \& E)$ Dorsal and lateral view of pygidium and the posteriormost thoracic segment of Holmia inusitata (PMO 234.290). Note indentation on the posterior margin of the terminal axial piece. Same as Fig. 13C. Lauselva, 1.5-2.0 $m$ level. (C) Dorsal view of partially preserved pygidium of Holmia lapponica (SGU Type 5225), erratic from Kyrkberget, Lake Storuman, Sweden. (Original of Ahlberg et al., 1986, fig. 5). (F) Pygidium of small Holmia kjerulfi (PMO 22970). Note indentation on posterior margin of terminal axial piece. Silicon cast of counterpart of specimen previously figured by Kicer (1917, pl. 8:1). Upper part of Tømten Member (Holmia Shale), Tømten Farm, Mjøsa area, Norway. All scale bars $=1 \mathrm{~mm}$.

(Fig. 16F) are very similar, the single pygidium known from H. lapponica (Fig. 16C) is poorly preserved but seems to be less vaulted and more effaced with no traces of pleural furrows or ridges.

\section{Ontogeny in Holmia}

Despite the rather high number of described and figured Baltoscandian olenellid taxa, different ontogenetic moulting stages of protaspid and meraspid specimens are rare. Kiær's (1917) description and figures of a series of stages of Holmia kjerulfi from the Tømten Member, Ringstranda Formation in the Mjøsa area and surroundings, together with vast material of holaspids, makes this species the best known olenellid taxon in Baltoscandia. Moczydłowska et al. (2001) figured two small, partially preserved cranidia of Holmia sp. from the Grammajukku Formation in the Lake Storuman area, Sweden. Høyberget et al. (2015) figured a nearly complete specimen with fourteen thoracic segments and three cephala of different meraspid stages of Holmia cf. lapponica from the Evjevika Member, Ringstranda Formation in the Mjøsa area. The figured specimens of these three Holmia species display morphological differences in late meraspids of comparable size. A protaspid stage is hitherto only known from a single specimen of $H$. kjerulfi, which is thoroughly treated by Kiær (1917) and Størmer (1942).
Meraspid moulting stages of Holmia inusitata are presented herein for the first time, collected from the Flagstadelva river section at the $12.5 \mathrm{~m}$ level. The present material consists of six, partial, meraspid cranidia with glabellar lengths from $2.1 \mathrm{~mm}$ to $6.4 \mathrm{~mm}$ and more than twenty partial holaspid cranidia with glabellar lengths ranging from $8.0 \mathrm{~mm}$ to $31.9 \mathrm{~mm}$. Although there are no specimens preserved with a complete number of thoracic segments, specimens with a cephalic length of $8 \mathrm{~mm}$ or longer have developed mature characters and proportions (Fig. 9D, Table 1). Kiær (1917, p. 68) noted that specimens of $H$. kjerulfi showed mature characters when the cephalic length reached $10 \mathrm{~mm}$. During ontogeny, the relative length of the frontal lobe increases relative to the entire length of the glabella (see discussion of measurements).

The smallest specimen, $2.1 \mathrm{~mm}$ in glabellar length (Fig. 17A), has a parallel-sided and narrow (tr.) glabella, distinct transglabellar S3 and occipital furrows. All glabellar furrows are straight and transversally directed, and S1 and S2 are very short. Although not wellpreserved, the frontal lobe seems to be short and poorly developed. The base of a small spine or node is medially placed on the occipital lobe and a distinct intergenal ridge is preserved on the left side. The ocular lobes are long, slender and curved, with the posterior ends opposite the anterior part of LO. The interocular area is comparatively wide and the combined width (tr.) of the ocular lobe and the interocular area is as wide as glabellar lobe L2. 

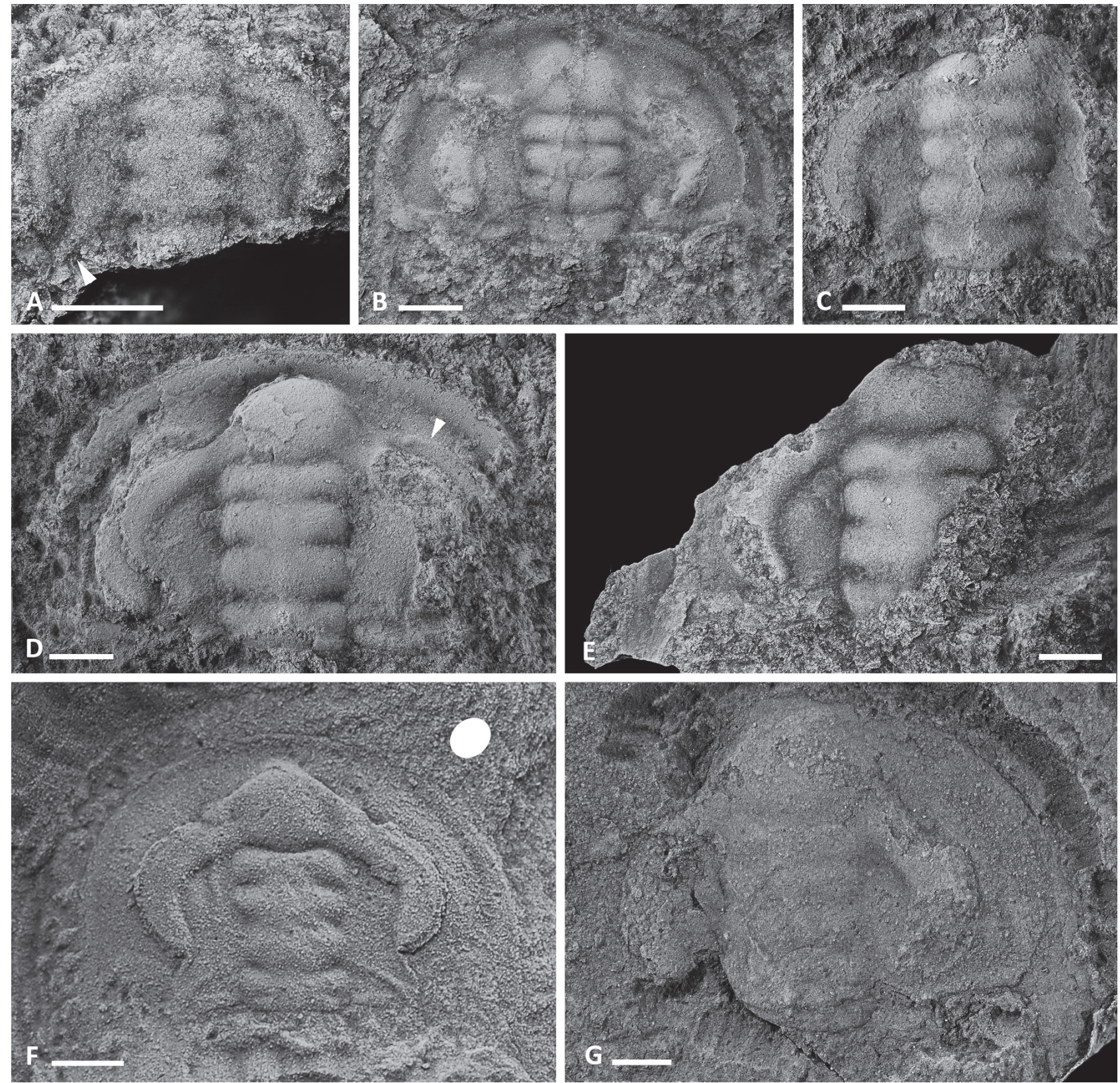

Figure 17. (A-E) Meraspid stages of Holmia inusitata. (A) Smallest collected cephalon (PMO 234.265), 2.1 mm in glabellar length. Arrow points to coarse intergenal ridge. Note transglabellar S3. (B) Small cephalon (PMO 234.266), $3.3 \mathrm{~mm}$ in glabellar length showing development of genal spines, occipital spine, intergenal ridge and prominent border. (C) Partial cephalon with well-preserved palpebral lobe (PMO 234.267). (D) Well-preserved cephalon (PMO 234.268/1), dorsal view. Arrow points to anterior metaparian suture. (E) Partial cephalon (PMO 234.269) with distinctly transglabellar S3, posterior border and inner genal angle preserved. All specimens collected at Flagstadelva, at the $12.5 \mathrm{~m}$ level. (F) Holmia cf. lapponica, retrodeformed cephalon (PMO 227.630) of meraspis stage, with strain ellipse. Ellipsostrenua linnarssoni Zone, Evjevika Member, Skyberg. Mjøsa area (original of Høyberget et al., 2015, fig. 6O). (G) Holmia sp., cephalon (PMU 24235) of meraspis stage. Schmidtiellus mickwitzi Zone, Grammajukku Formation near Storuman, northern Sweden (original of Moczydlowska et al., 2001, fig. 7a), prior to preparation. All scale bars $=1 \mathrm{~mm}$.

A cephalon of $H$. kjerulfi of comparable size, figured by Kiær (1917, pl. 8, fig. 2), shows all glabellar furrows to be transglabellar and the combined width of the ocular lobe and the interocular area is narrower than glabellar lobe L2, and comparatively narrower than seen in H. inusitata.

In a complete but flattened cephalon, $3.3 \mathrm{~mm}$ in glabellar length (Fig. 17B), the frontal lobe has grown proportionally larger than in the smallest specimen, but is separated from the border furrow by a short preglabellar field. The intergenal ridge is less pronounced compared to the smaller stage, and reaches the posterior margin in line (exsag.) with the inner part of the posterior end of the ocular lobe. The glabella is parallel-sided and narrow and the posterior end of the ocular lobes is adjacent to the anterior part of LO. The width (tr.) of L2 exceeds the combined width of the interocular area and the ocular lobe at this stage. A concave cephalic border, uniform in 
width, is well-developed with a distinct border furrow. The genal spine is approximately half as long as the cephalon. The posterior border is straight between the glabella and the intergenal node, while the distal portion forms an anteriorly directed arch. Cranidia of $H$. kjerulfi (Kiær, 1917, pl. 6, fig. 3) and H. cf. lapponica (Høyberget et al., 2015, fig. 6N, O (the latter refigured in Fig. 17F herein)) of broadly similar size, also show an arcuate lateral posterior border. The ocular lobes in these two species are shorter and the cephalic border is less distinct, compared with $H$. inusitata (see Fig. 17F).

The next stage represented in the $H$. inusitata material has a glabellar length of $4.5 \mathrm{~mm}$ (Fig. 17D), which can best be compared with a slightly larger cephalon of $H$. cf. lapponica (Høyberget et al., 2015, fig. 6P). The glabella in $H$. inusitata is parallel-sided and narrow and the frontal lobe is short. The base of a distinct spine is medially placed on LO. Metaparian sutures are developed at this stage, which may be interpreted as being important in the species' functional morphology. This is seen as a faint ridge running from the anterior end of the compound eye in a laterally backward direction, crossing the extraocular area (Fig. 17D).

A poorly preserved posterior border in Fig. 17E seems to be weakly arcuate at this size.
H. cf. lapponica has developed a swollen frontal lobe at this size and the posterior border is different from $H$. inusitata by having a zigzagged marginal line. The cephalic border is less pronounced and the border furrow is shallow compared with $H$. inusitata. The smallest specimen of $H$. sp. (Moczydłowska et al., 2001, fig. 7a) has a glabellar length around $5 \mathrm{~mm}$. Preparation of this specimen (PMU 24235) revealed a nearly complete cephalon (Fig. 17G herein). The frontal lobe is slightly expanded and nearly reaches the anterior margin. The frontal lobe and L3 are somewhat wider than the posterior portion of the glabella and the interocular area is narrow compared to the slightly smaller specimen of $H$. inusitata. The ocular lobes are not as curved as seen in other Holmia species. Another dissimilarity to $H$. inusitata is the more posteriorly placed occipital spine. The long ocular lobes, extending backwards to a transverse line opposite the midst of the occipital lobe, is also seen in H. inusitata at this size (Fig. 17D). An almost complete specimen of $H$. cf. lapponica (Høyberget et al., 2015, fig. 6M) of approximately the same ontogenetic stage has fourteen thoracic segments, which shows that this is a late meraspid stage.

A cephalon with well-preserved right side and glabellar length of $6.4 \mathrm{~mm}$ (Fig. 18A-E) probably corresponds to Kiær's 'late neanic stage' (1917, pp. 66-88), representing
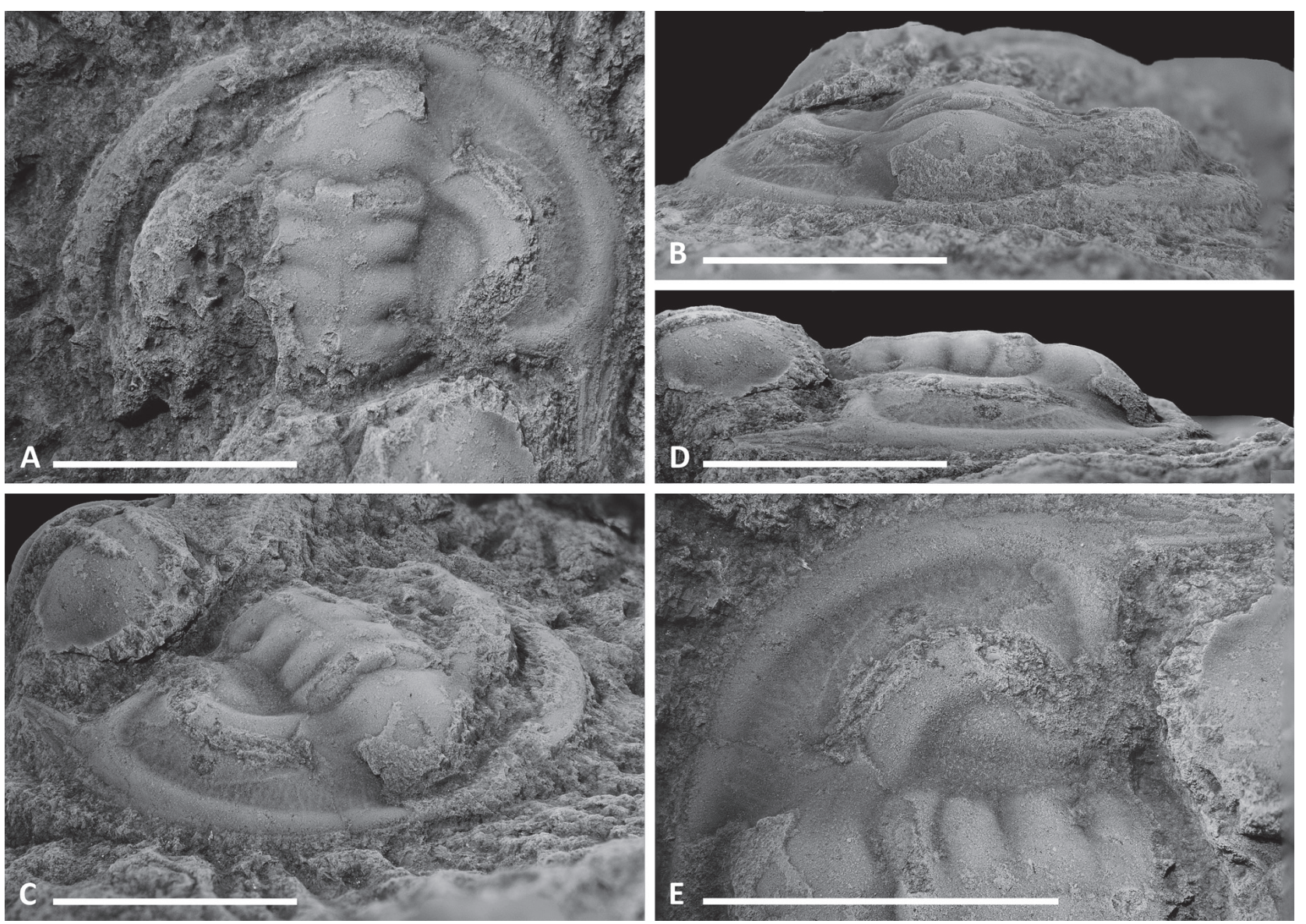

Figure 18. Holmia inusitata. (A-E) Late meraspid or early holaspid stage. Different views of well-preserved right side of cephalon (PMO 234.270/1), $6.4 \mathrm{~mm}$ in glabellar length. Note genal caeca and anterior metaparian suture. Flagstadelva, $12.5 \mathrm{~m}$ level. All scale bars $=5 \mathrm{~mm}$. 

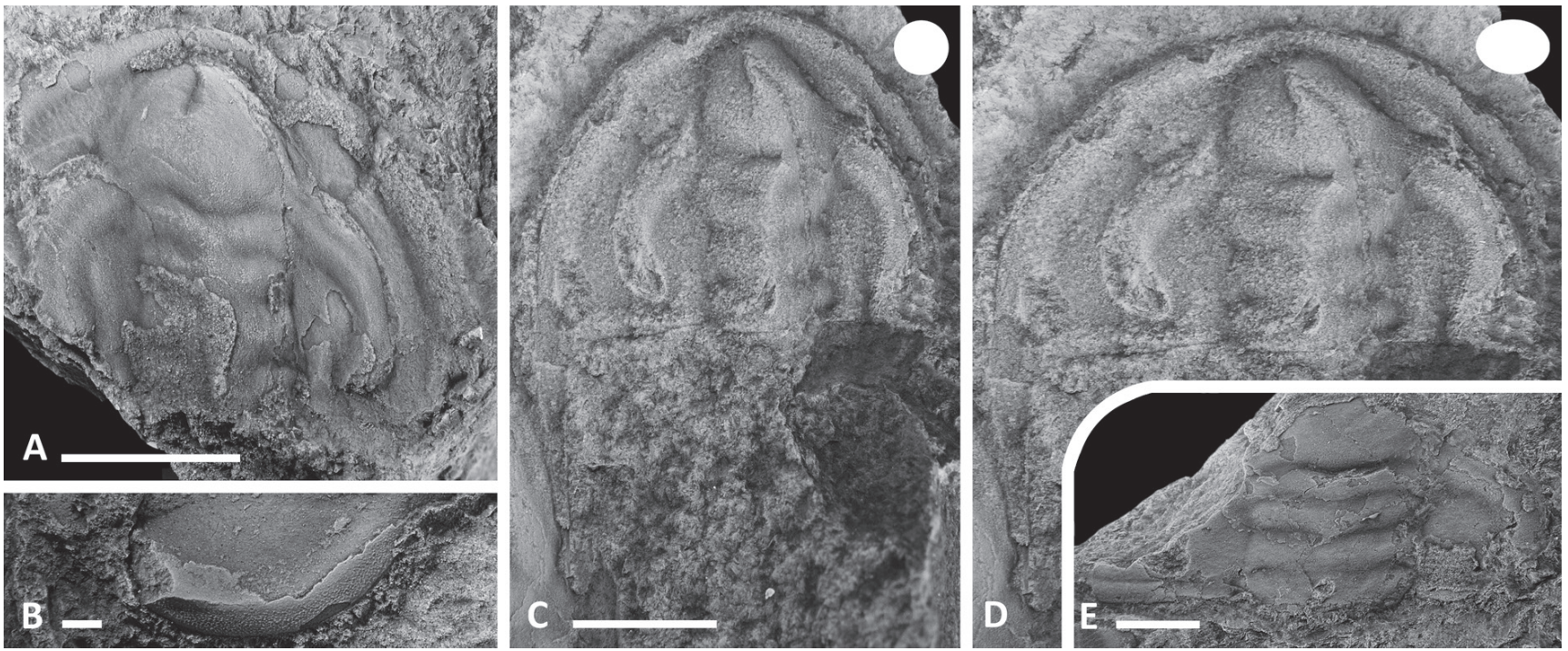

Figure 19. Holmia inusitata. (A) Laterally deformed cephalon (PMO 234.272/1) with genal caeca and anterior metaparian suture. See Fig. 9D for retrodeformed image of this specimen. (B) Detail of fragmentary cephalon (PMO 234.278) with reticulate pattern preserved on palpebral lobe. (C \& D) Laterally deformed cephalon, retrodeformed with strained ellipse in D, (PMO 234.273/1) showing long and straight genal spine. (E) Sagittally deformed cephalon (PMO 234.272/2). Note the glabellar furrows that appear transglabellar. All specimens collected at Flagstadelva, at the $12.5 \mathrm{~m}$ level. Scale bars on $A, C-E=5 \mathrm{~mm}, B=1 \mathrm{~mm}$.

a very late meraspid or an early holaspid stage. At this size, H. inusitata has developed several mature characters like the proportionally wider glabella and a longer and weakly expanded frontal lobe almost abutting the anterior border. The L3 has changed into an undulating shape and is slightly widened compared to L1 and L2. The S3 furrow is distinctly undulating and the S1 and S2 show a posterior adaxial direction. The base of the occipital spine is coarse. Further, the cephalic border has developed an uneven width and the combined width of the ocular lobe and the interocular area is markedly narrower than L2. The extraocular cheek is equipped with distinct caeca, best developed close to the border furrow. A larger specimen of $H$. sp. (Moczydłowska et al., 2001 , fig. 7c) is quite similar to $H$. inusitata at this or a close stage in having the proportionally wider glabella with an undulating S3, a larger frontal lobe and straight posterior cephalic border. The Swedish specimen differs from $H$. inusitata by the narrower extraocular area. The weaker cephalic border furrow and the flattened cephalic border in $H$. sp. may be due to different degrees of lithological preservation.

In an early holaspid specimen, with a glabellar length of $8.0 \mathrm{~mm}$ (Figs. 9D \& 19A), the cephalon has developed mature characters. This is seen in the proportionally wide glabella with a rounded and large frontal lobe possessing a parafrontal band, and the glabellar furrows are curved and long and the cephalic border is narrower medially than postero-laterally. This specimen shows genal caeca close to the border furrow.

The largest specimen collected from Flagstadelva (Fig. $10 \mathrm{~A}, \mathrm{C}$ ) has a glabellar length of $31.9 \mathrm{~mm}$, indicating a total width of some $\sim 64 \mathrm{~mm}$ of the cephalon. Skjeseth's original specimen (Fig. 9A) has a glabellar length of 26.2 $\mathrm{mm}$ and a restored total cephalic width of $\sim 53 \mathrm{~mm}$. The largest specimen collected from the autochthonous strata at the Lauselva locality (the holotype) has a glabellar length of $30.5 \mathrm{~mm}$ and a restored cephalic width of around $60 \mathrm{~mm}$. The very large, partially preserved single cephalon of $H$. grandis Kiær, 1917, from the Tømten Member, Mjøsa area, has a restored cephalic width of 80 $\mathrm{mm}$. Among the very rich material of $H$. kjerulfi from the same area, all housed at the Natural History Museum, Oslo, the largest cephalon shows a maximum width of 54 $\mathrm{mm}$.

\section{Conclusions}

The previously assumed stratigraphic level of the single specimen of Holmia cf. mobergi low in the Flagstadelva section in the Mjøsa area, Norway, is here considered erroneous. Additional material of the taxon figured in this work originates from a much higher stratigraphic horizon, namely the lower part of the Tømten Member, Ringstranda Formation. This is within the Heliosphaeridium dissimilare-Skiagia ciliosa acritarch Zone, according to Vidal \& Nystuen (1990). Comparison of the new material from Flagstadelva and that of new topotype material of Holmia inusitata from the Lauselva section in the Mjøsa area demonstrates that Holmia cf. mobergi is conspecific with Holmia inusitata. The species is recorded from autochthonous and parautochthonous lower Cambrian strata in the Mjøsa area that are very 
sparsely fossiliferous with no other trilobite taxa known. It is therefore argued that the Holmia inusitata Zone should be maintained as a local biozone in the Mjøsa area, predating the Holmia kjerulfi Zone which everywhere in Baltoscandia shows a much higher diversity.

Re-evaluation of other fossil occurrences in the Flagstadelva section also suggests that reports of both the enigmatic fossil Mobergella and the rich trace-fossil assemblage are erroneous. The implications are that the Redalen Member of the Caledonian Lower Allochthon in the Mjøsa area, containing abundant trace fossils, and the Bråstad Sandstone (here informally termed the Bråstadelva member) at the Bråstadelva locality in the Mjøsa area, containing mobergellans, belong to the older Schmidtiellus mickwitzi Zone. Re-interpretation of the traditional lower and middle Cambrian boundary in the Flagstadelva section further suggests that the parautochthonous strata, postdating the Hawke Bay regression event, were developed during the midCambrian Ptychagnostus atavus Zone and not during Acadoparadoxides oelandicus time or at the age of the Ptychagnostus gibbus Zone, as previously stated.

Acknowledgements. This contribution is under the framework of the Digermulen Early Life Research Group (Research Council of Norway, grant No. 231103). Sören Jensen, Badajoz, Spain, and Anette Högström, Tromsø, Norway, are thanked for careful reading of the manuscript. We thank Helje Pärnaste, Tallinn, Estonia, and Anna Żylińska, Warsaw, Poland for constructive reviews. Franz-Josef Lindemann, Natural History Museum, Oslo, is thanked for helping with specimens stored in the museum collections. The Swedish Geological Survey, the Lund University, Sweden, and the Museum of Evolution, Uppsala, Sweden, are thanked for loan of important specimens used in this study. Magnus Høyberget, Roksvoll, is shown gratitude by MH for important field assistance.

\section{References}

Ahlberg, P. 1984: Lower Cambrian trilobites and biostratigraphy of Scandinavia. Lund Publications in Geology 22, 1-37.

Ahlberg, P. 1985: Lower Cambrian trilobite faunas from the Scandinavian Caledonides-a review. In Gee, D.G. \& Sturt, B.A. (eds.): The Caledonide Orogen - Scandinavia and Related Areas, Part 1, Wiley, Chichester, pp. 339-346.

Ahlberg, P. \& Bergström, J. 1978: Lower Cambrian ptychopariid trilobites from Scandinavia. Sveriges Geologiska Undersökning C49, $1-41$.

Ahlberg, P., Bergström, J. \& Johansson, J. 1986: Lower Cambrian olenellid trilobites from the Baltic Faunal Province. Geologiska Föreningens i Stockholm Förhandlingar 108, 39-56. https://doi.org/10.1080/11035898609453745.

Ahlberg, P., Cederström, P. \& Babcock, L.E. 2016: Cambrian Series 2 biostratigraphy and chronostratigraphy of Scandinavia: a reappraisal. Abstracts, Palaeo Down Under 2, Adelaide 11-15 July 2016.

Bengtson, S. 1977: Aspects of problematic fossils in the early Palaeozoic. Acta Universitatis Upsaliensis, Abstracts of Uppsala Dissertations from the Faculty of Sciences 415, 1-71.
Bergström, J. 1973: Classification of olenellid trilobites and some Balto-Scandian species. Norsk Geologisk Tidsskrift 53, 283-314.

Bergström, J. 1980: The Caledonian margin of the Fennoscandian shield during the Cambrian. In Wones, D.R. (ed.): The Caledonides in the U.S.A. Virginia Polytechnic Institute and State University Department of Geological Sciences. Memoir 2, pp. 9-13.

Bergström, J. 1981: Lower Cambrian shelly faunas and biostratigraphy in Scandinavia. In Taylor, M.E. (ed.): Short papers for the Second International Symposium on the Cambrian System 1981, U.S. Geological Survey Open-File Report 81-743, pp. 22-25.

https://doi.org/10.1080/11035898109454518.

Bergström, J. \& Ahlberg, P. 1981: Uppermost Lower Cambrian biostratigraphy in Scania, Sweden. Geologiska Föreningens $i$ Stockholm Förhandlingar 103, 193-214.

Bergström, J. \& Gee, D.G. 1985: The Cambrian in Scandinavia. In Gee, D.G. \& Sturt, B.A. (eds): The Caledonide Orogen - Scandinavia and Related Areas, Part 1, Wiley, Chichester, pp. 247-271.

Bjørlykke, A. 1979: Gjøvik og Dokka. Beskrivelse til de berggrunnsgeologiske kart 1816 I og 1816 IV (M 1:50 000). Norges Geologiske Undersøkelse 344, 1-48.

Bråstad, J. 1915: Discinella holsti faunaen ved Braastadelven nord for Gjøvik. Norsk Geologisk Tidsskrift 3, 1-16.

Daily, B. 1972: The base of the Cambrian and the first Cambrian faunas. In Jones, J.B. \& McGowran, B. (eds): Stratigraphic problems of the later Precambrian and Early Cambrian, Centre for Precambrian Research, University Adelaide Special Paper 1, pp. 13-37.

Demidenko, Y.E. 2016: Morphology, taxonomic position and stratigraphic distribution of the Early Cambrian skeletal problematics Mobergella radiolata Bengtson, 1968. Paleontological Journal 50, 435-449. https://doi.org/10.1134/S003103011605004X.

Ebbestad, J.O.R., Ahlberg, P. \& Høyberget, M. 2003: Redescription of Holmia inusitata (Trilobita) from the Lower Cambrian of Scandinavia. Palaeontology 46, 1039-1054. https://doi.org/10.1111/1475-4983.00332.

Ebbestad, J.O.R, Høyberget, M., Högström, A.E.S, Palacios, T., Jensen, S., Taylor, W. \& Meinhold, G. 2017: Holmiid trilobites from the lower Cambrian of the Digermulen Peninsula, Arctic Norway. Abstracts, 6th International Conference on Trilobites and their Relatives, Tallinn, Estonia 2017.

Fritz, W.H. 1995: Esmeraldina rowei and associated Lower Cambrian trilobites (1f fauna) at the base of Walcott's Waucoban Series, southern Great Basin, U.S.A. Journal of Paleontology 69, 708-723. https://doi.org/10.1017/S002233600003523X.

Føyn, S. \& Glaessner, M.F. 1979: Platysolenites, other animal fossils, and the Precambrian-Cambrian transition in Norway. Norsk Geologisk Tidsskrift 59, 25-46.

Hamar, G. 1967: Platysolenites antiquissimus Eichw. (Vermes) from the Lower Cambrian of Norway. Norges Geologiske Undersøkelse 249, $87-95$.

Hammer, Ø., Harper, D.A.T. \& Ryan, P.D. 2001: PAST: Palaeontological statistics software package for education and data analysis. Palaeontologia Electronica 4(1), 1-9.

Harrington, H.J. 1959: General description of trilobita. In Moore, R.C. (ed.): Treatise on invertebrate paleontology. Part O. Arthropoda 1, Geological Society of America and University of Kansas Press, pp. 38-126.

Henningsmoen, G. 1956: The Cambrian of Norway. XX Congreso Geológico International. XX sesión, Mexico. El sistema Cámbrico, su paleogeografía y el problema de su base, I, 45-57.

Henningsmoen, G. 1960: Cambro-Silurian deposits of the Oslo Region. In Holtedahl, O. (ed.): Geology of Norway, Norges Geologiske Undersøkelse 208, pp. 130-150.

Hupé, P. 1953: Contribution à létude du Cambrien inférieur et du Précambrian III de l'Anti- Atlas Marocain. Direction de la Production Industrielle et des Mines, Division des Mines et de la Géologie, Service Géologique, Notes et Mémoires 103, 1-402. 
Høyberget, M. \& Bruton, D.L. 2008: Middle Cambrian trilobites of the suborders Agnostina and Eodiscina from the Oslo Region, Norway. Palaeontographica A286, 1-87.

Høyberget, M., Ebbestad, J.O.R., Funke, B. \& Nakrem, H.A. 2015: The shelly fauna and biostratigraphy of the lower Cambrian (provisional series 2, stage 4) Evjevik Member, Ringstrand Formation in the Mjøsa area, Norway. Norwegian Journal of Geology 95, 23-56.

Jensen, S. 1997: Trace fossils from the Lower Cambrian Mickwitzia sandstone, south-central Sweden. Fossils \& Strata 42, 1-110.

Jensen, S. \& Grant, S.W.F. 1998: Trace fossils from the Dividalen Group, northern Sweden: implications for Early Cambrian biostratigraphy of Baltoscandia. Norsk Geologisk Tidsskrift, 78, 305-317.

Jensen, S., Palacios, T. \& Martí-Mus, M. 2010: Revised biochronology of the Lower Cambrian of the Central Iberian zone, southern Iberia massif, Spain. Geological Magazine 147, 690-703. https://doi.org/10.1017/S0016756809990677.

Kiær, J. 1917: The Lower Cambrian Holmia fauna at Tømten in Norway. Norske Videnskapsselskapets Skrifter, I. MatematiskNaturvitenskablig Klasse 1916, 10, 1-140.

Liebermann, B.S. 1999: Systematic Revision of the Olenelloidea. Bulletin of the Peabody Museum of Natural History 45, 1-150.

Martinsson, A. 1974: The Cambrian of Norden. In Holland, C.H. (ed.): Lower Palaeozoic Rocks of the World, Vol. 2, Cambrian of the British Isles, Norden, and Spitsbergen, Wiley - Interscience, London, pp. 185-283.

Matthew, G.F. 1890: On Cambrian organisms in Acadia. Royal Society of Canada, Proceedings and Transactions 7, 135-162.

Mens, K., Bergström, J. \& Lendzion, K. 1990: The Cambrian System on the East European Platform, Correlation Chart and Explanatory Notes. International Union of Geological Sciences Publication 25, $1-73$.

Moczydłowska, M. 1991: Acritarch biostratigraphy of the Lower Cambrian and the Precambrian-Cambrian boundary in southeastern Poland. Fossils \& Strata 29, 1-127.

Moczydłowska, M. 2002: Early Cambrian phytoplankton diversification and appearance of trilobites in the Swedish Caledonides with implications for coupled evolutionary events between primary producers and consumers. Lethaia 35, 191-214. https://doi.org/10.1080/00241160260288802.

Moczydłowska, M. \& Vidal, G. 1986: Lower Cambrian acritarch zonation in southern Scandinavia and southeastern Poland. Geologiska Föreningens i Stockholm Förhandlingar 108, 201-223. https://doi.org/10.1080/11035898609454685.

Moczydłowska, M., Jensen, S., Ebbestad, J.O.R., Budd, G.E. \& MartíMus, M. 2001: Biochronology of the autochthonous Lower Cambrian in the Laisvall-Storuman area, Swedish Caledonides. Geological Magazine 138, 435-453. https://doi.org/10.1017/S0016756801005416.

Nielsen, A.T. \& Schovsbo, N.H. 2007: Cambrian to basal Ordovician lithostratigraphy in southern Scandinavia. Bulletin of the Geological Society of Denmark 53, 47-92.

Nielsen, A.T. \& Schovsbo, N.H. 2011: The Lower Cambrian of Scandinavia: Depositional environment, sequence stratigraphy and palaeogeography. Earth Science Reviews 107, 207-310. https://doi.org/10.1016/j.earscirev.2010.12.004.

Nielsen, A.T. \& Schovsbo, N.H. 2015: The regressive Early-Mid Cambrian "Hawke Bay Event" in Baltoscandia: Epeirogenic uplift in concert with eustacy. Earth-Science Reviews 151, 288-350. https://doi.org/10.1016/j.earscirev.2015.09.012.

Nikolaisen, F. \& Henningsmoen, G. 1987: Lower and Middle Cambrian trilobites from the Digermul peninsula, Finnmark, northern Norway. Norges Geologiske Undersøkelse. Bulletin 419, 55-95.
Nystuen, J.P. 1981: The Late Precambrian 'Sparagmites' of southern Norway: A major Caledonian allochthon - the Osen-Røa Nappe Complex. American Journal of Science 281, 69-94. https://doi.org/10.2475/ajs.281.1.69.

Owen, A.W., Bruton, D.L., Bockelie, J.F. \& Bockelie, T.G. 1990: The Ordovician successions of the Oslo Region, Norway. Norges Geologiske Undersøkelse, Special Publications 4, 3-54.

Palacios, T., Högström, A.E.S, Ebbestad, J.O.R., Jensen, S., Høyberget, M., Meinhold, G., \& Taylor, W. 2015: Acritarchs from the Duolbagáisa and Kistedalen formations (Cambrian Series 2-3), Digermulen Peninsula, northern Norway. Abstracts, CIMP Meeting 16-19 September 2015, Bergen, Norway.

Schoenemann, B., Pärnaste, H. \& Clarkson, E.N.K. 2017: Structure and function of a compound eye, more than half a billion years old. Proceedings of the National Academy Sciences of the United States of America 114, 13489-13494.

https://doi.org/10.1073/pnas.1716824114.

Skjeseth, S. 1963: Contributions to the geology of the Mjøsa Districts and the classical sparagmite area in southern Norway. Norges Geologiske Undersøkelse 220, 1-126.

Størmer, L. 1942: Studies on trilobite morphology part II. The larval development, the segmentation and the sutures, and their bearing on trilobite classification. Norsk Geologisk Tidsskrift 21, 49-164.

Vidal, G. 1981a: Lower Cambrian acritarch stratigraphy in Scandinavia. Geologiska Föreningens i Stockholm Förhandlingar 103, 183-192. https://doi.org/10.1080/11035898109454517.

Vidal, G. 1981b: Micropaleontology and biostratigraphy of the lower Cambrian sequence in Scandinavia. In Taylor, M.E. (ed.): Short papers for the Second International Symposium on the Cambrian System 1981, United States Geological Survey, Open File Report 81-743, pp. 232-235.

Vidal, G. \& Nystuen, J.P. 1990: Lower Cambrian acritarchs and the Proterozoic-Cambrian boundary in southern Norway. Norsk Geologisk Tidsskrift 70, 191-222.

Vidal, G., Palacios, T., Díez-Balda, M.A., Gámez-Vintaned, J.A. \& Grant, S.W.F. 1994: Neoproterozoic-early Cambrian geology and palaeontology of Iberia. Geological Magazine 131, 729-65. https://doi.org/10.1017/S001675680001284X.

Vidal, G. \& Moczydłowska-Vidal, M. 1997: Biodiversity, speciation, and extinction trends of Proterozoic and Cambrian phytoplankton. Paleobiology 23, 230-246. https://doi.org/10.1017/S0094837300016808.

Vogt, T. 1924: Forholdet mellem sparagmitsystemet og det marine underkambrium ved Mjøsen. Norsk Geologisk Tidsskrift 7, 281-384.

Walcott, C.D. 1890: The fauna of the Lower Cambrian or Olenellus Zone. Tenth Annual Report of the United States Geological Survey, 509-761.

Webster, M. \& Hughes, N.C. 1999: Compaction-related deformation in Cambrian olenelloid trilobites and its implications for fossil morphometry. Journal of Paleontology 73, 355-371. https://doi.org/10.1017/S0022336000027827.

Whittington, H.B. 1987: Hypostomes and ventral cephalic sutures in Cambrian trilobites. Palaeontology 31, 577-609.

Whittington, H.B. 1990: Articulation and exuviation in Cambrian trilobites. Philosophical Transctions of the Royal Society of London B329, 27-46. 
Whittington, H.B. 1997: Morphology of the exoskeleton. In Whittington et al. (eds): Treatise on Invertebrate Paleontology, Part 0, Arthropoda 1, Trilobita (revised). Volume 1, The Geological Society of America and University of Kansas Press, New York and Lawrence, Kansas, pp. 1-85.

Worsley, D., Aarhus, N., Bassett, M.G., Howe, M.P.A., Mørk, A. \& Olaussen, S. 1983: The Silurian succession of the Oslo Region. Norges Geologiske Undersøkelse 384, 1-57.

Yochelson, E.L., Henningsmoen, G. \& Griffin, W.L. 1977: The Early Cambrian genus Volborthella tenuis in southern Norway. Norsk Geologisk Tidsskrift 57, 133-151.

Zhang, X., Ahlberg, P., Babcock, L.E., Choi, D.K., Geyer, G., Gozalo, R., Hollingsworth, J.S., Li, G., Naimark, E.B., Pegel, T., Steiner, M., Wotte, T. \& Zhang, Z. 2017: Challenges in defining the base of Cambrian Series 2 and Stage 3. Earth-Science Reviews 172, 124-139. https://doi.org/10.1016/j.earscirev.2017.07.017.

Żylińska, A., Kin, A. \& Nowicki, J. 2013: Application of morphometric techniques for taxonomic revision of Berabichia oratrix (Orłowski, 1985) (Trilobita, Cambrian) from the Holy Cross Mountains, Poland. Geodiversitas 35, 505-528.

https://doi.org/10.5252/g2013n3a1. 
